\title{
The Effects of Structural Reforms on Productivity and Profitability Enhancing Reallocation: Evidence from Colombia*
}

\author{
Marcela Eslava, John Haltiwanger, Adriana Kugler and Maurice Kugler ${ }^{\dagger}$
}

May 15, 2004

\begin{abstract}
Estimates for the U.S. suggest that at least in some sectors productivity enhancing reallocation is the dominant factor in accounting for producitivity growth . An open question, particularly relevant for developing countries, is whether reallocation is always productivity enhancing. It may be that imperfect competition or other barriers to competitive environments imply that the reallocation process is not fully efficient in these countries. Using a unique plant-level longitudinal dataset for Colombia for the period 1982-1998, we explore these issues by examining the interaction between market allocation, and productivity and profitability. Moreover, given the important trade, labor and financial market reforms in Colombia during the early 1990's, we explore whether and how the contribution of reallocation changed over the period of study. Our data permit measurement of plant-level quantities and prices. Taking advantage of the rich structure of our price data, we propose a sequential mehodology to estimate productivity and demand shocks at the plant level. First, we estimate total factor productivity (TFP) with plant-level physical output data, where we use downstream demand to instrument inputs. We then turn to estimating demand shocks and mark-ups with
\end{abstract}

${ }^{*}$ We thank Alberto Serrano, Juan Manuel Contreras and Pablo Medina for excellent research assistance, Alvaro Suárez and José Eduardo Granados at DANE for providing access to data, the staff in charge of the AMS for answering our queries on methodological issues regarding the data, and participants at various seminars at DANE for their comments and suggestions. We thank the participants of the IASE conference in Chile in November 2003 and, especially, Andy Bernard, Raphael Bergoeing, Jon Eaton, Sebastian Edwards, Mark Roberts and Ernesto Schargrodsky for excellent comments. Support for this project was provided by the World Bank. John Haltiwanger also acknowledges financial support from the NSF and the IDB, Adriana Kugler from the Spanish Ministry of Science and Technology through grant No. SEC-2003-04429, and Maurice Kugler from the IDB.

${ }^{\dagger}$ Marcela Eslava: University of Maryland and Universidad de Los Andes/CEDE, e-mail: eslava@econ.umd.edu. John Haltiwanger: University of Maryland and NBER, e-mail: haltiwan@econ.umd.edu. Adriana Kugler: University of Houston, Universitat Pompeu Fabra, CREA, CEPR and IZA, e-mail: adkugler@uh.edu. Maurice Kugler: University of Southampton, e-mail: maurice.kugler@soton.ac.uk. 
plant-level price data, using TFP to instrument for output in the inversedemand equation. We examine the evolution of the distributions of TFP and demand shocks in response to the market reforms in the 1990's. We find that market reforms are associated with rising overall productivity that is largely driven by reallocation away from low- and towards highproductivity businesses. In addition, we find that the allocation of activity across businesses is less driven by demand factors after reforms. We find that the increase in aggregate productivity post-reform is entirely accounted for by the improved allocation of activity.

JEL Classification Codes: E23, L16, L60, O14, O24, O54.

Keywords: TFP Measurement, Productivity and Demand Decompositions, Structural Reforms.

\section{Introduction}

Market economies are continually restructuring in response to changing conditions. The burgeoning evidence from longitudinal micro business databases has shown that productivity growth at the aggregate level is closely connected to the efficiency of the economy at the micro level to allocate outputs and inputs across businesses. That is, a large fraction of measured productivity growth is accounted for by more productive expanding businesses displacing less productive contracting businesses. ${ }^{1}$

These issues loom especially large in developing economies - although, they have hardly been settled in advanced economies. In developing economies, there are potentially a variety of barriers to promoting efficient ongoing reallocation. These barriers might stem from distortions in market structure as well as the market institutions and policies in place. Aware of the impediments that distortionary policies may place on reallocation and, more generally, on productivity growth, during the past decade Latin American countries have undertaken a whole series of reforms (including, labor, financial, and trade reforms) to promote flexibility.

In this paper, we characterize the evolution of the distributions of productivity and other determinants of profitability such as demand factors in Colombia, one of the Latin American economies that underwent extensive structural reforms in the early nineties. The role of productivity vs. other components of profitability is critical in evaluating the market-oriented reforms in Latin America since the reforms were intended to enhance the role of productivity and perhaps reduce the role of demand factors (especially to the extent to which markets were artificially imperfectly competitive) in the allocation of activity. We examine the relationship between the allocation of activity, on the one hand, and productivity and demand factors on the other. ${ }^{2}$ We then ask how this rela-

\footnotetext{
${ }^{1}$ For the labor market, the efficient churning of businesses implies a need to reallocate jobs at a high pace without long and costly spells of unemployment. The latter is important for not only productive efficiency of the economy but also obviously important for welfare.

${ }^{2}$ In our analysis, we focus on some of the main determinants of profitability, including productivity, demand and output prices. There are other determinants of profitability, such
} 
tionship changed after market reforms were introduced in Colombia in the early 1990's.

Colombia is a superb country to study these issues for two reasons. First, Colombia underwent a substantial and relatively fast market reform process, mainly in 1990 and 1991. The 1990 labor market reform, which introduced individual severance payments savings accounts, reduced dismissal costs by between $60 \%$ and $80 \%$ (Kugler $(1999,2004)$ ). The 1991 trade liberalization reduced the average tariff from over $62 \%$ to around $15 \%$ (Lora (1997)). The financial reform first introduced in 1990 and extended in 1991, liberalized deposit rates, eliminated credit subsidies and modernized capital market and banking legislation (Lora (1997)). In addition, restrictions on inflows of foreign direct investment (FDI) were removed in 1991 as multinational firms were given national treatment (Kugler (2000)). The 1993 social security reform allowed voluntary transfers from a pay-as-you-go system to a fully-funded system with individual accounts, though it increased employer and employee pension contributions up to $13.5 \%$ of earnings (Kugler and Kugler (2003)).

Second, Colombia has unique longitudinal microeconomic data on businesses. A unique feature of the Colombian data is that both plant-level quantities and prices can be measured. The ability to measure plant-level prices of both outputs and inputs is potentially very important in this context for both measurement and conceptual reasons. Much of the existing literature measures establishment output as revenue divided by a common industry-level deflator. Therefore, within-industry price differences are embodied in output and productivity measures. Moreover, if prices reflect idiosyncratic demand shifts or market power variation rather than quality or other differences in product attributes, then high "measured" productivity businesses may not be particularly efficient. In this sense, the relationship between productivity and reallocation in the literature may be misleading. ${ }^{3}$

In the context of a developing economy undergoing structural reforms these measurement and conceptual issues are especially important. A key objective of structural reforms is to make markets more competitive. Without the ability to measure plant-level prices it is very difficult to quantify and, in turn, analyze the respective contributions of demand and efficiency factors in the allocation of activity and how they may have changed in response to market reforms. In this paper, we attempt to measure the separate influences of idiosyncratic productivity and demand on the allocation of activity in Colombia.

In exploiting these unique micro data, our paper makes a number of re-

as costs, which are not the focus of our present analysis.

${ }^{3}$ Since Marschak and Andrews (1944), there has been awareness about the possible difficulties involved in using revenue-based deflated output in establishment level data. Klette and Griliches (1996) consider how intra-industry price fluctuations can affect production function and productivity estimates. Melitz (2000) explores this problem further and extends the analysis to consideration of multi-product producers. Katayama, Lu, and Tybout (2003) argue that both revenue-based output and expenditure-based input measures can lead to productivity mismeasurement and incorrect interpretations about how heterogeneous producers respond to shocks and the associated welfare implications. Foster, Haltiwanger and Syverson (2003) use plant-level data on quantities and prices for the U.S. to study market selection dynamics. 
lated methodological innovations relative to much of the literature. First, in measuring efficiency we estimate production functions using an extension of the instrumental variable approach pioneered by Shea (1993) and Syverson (2003). In the latter, Syverson uses local downstream demand instruments to estimate returns to scale of production functions. Building on this approach, we use downstream demand instruments as well as plant-level input prices for materials and energy as instruments in estimating production functions. From this structural estimation of production functions, we generate measures of plantlevel efficiency (i.e., plant-level total factor productivity). Second, since we can measure plant-level output prices, we estimate demand elasticities using the total factor productivity estimates as instruments in the demand equations. That is, we first use downstream demand instruments to estimate production functions and then use supply shocks (i.e., total factor productivity) to estimate the demand functions.

Having estimated production and demand functions, we study the evolution of the distributions of total factor productivity, demand shocks, and prices through the market reforms in Colombia. We find that aggregate TFP is higher after the reforms. Moreover, the dispersion of TFP also rises after the reforms. Our main focus though is on the allocation of activity and its relationship to TFP and demand shocks in Colombia throughout the entire period as well as during periods prior to and subsequent to the reforms. Overall, we find that the allocation of activity reflects both efficiency and demand factors. That is, market shares are higher for businesses that are more efficient and face higher demand. Following the reforms, we find that efficiency factors become more important in the allocation of activity across businesses while demand factors become less important. Interestingly, we find that the rising aggregate productivity in Colombia over this period is accounted for almost entirely by the improved allocation of activity across businesses.

At the extensive margin, we also find that exiting businesses are less efficient and face lower demand for their products relative to incumbents. On the other hand, entering businesses are more efficient than incumbents and exiting businesses, but also face lower demand relative to incumbents. This finding points to the importance of vintage technology rather than learning to account for productivity dynamics. Note that revenue-based TFP measures spuriously include a demand component and thus underestimate technical efficiency of entrants, who have to build a consumer base, relative to incumbents, who have a established clientele. Hence, the analysis in the present paper provides a better basis to discern between vintage and learning explanations for dynamics and heterogeneity in productivity.

How did these patterns change in response to the market reforms? After the market reforms, the positive gap between the productive efficiency of the average incumbent and the average exiting business rises but the positive gap between the productive efficiency of the average entering business and the average incumbent declines. On net, the contribution of entry and exit to average productivity rises slightly. Moreover, when we investigate a more dynamic specification we find that, after the reforms, entrants exhibit slightly higher 
productivity than incumbents . There is also evidence of learning effects in the post-reform period. Putting these pieces together suggests market reforms yielded a more heterogenous group of entrants but that conditional on survival the post- reform entrants contribute more to productivity. Increased learning by entering businesses after the reforms may be due to increased access to new imported capital vintages and increased access to know-how from foreign businesses. These patterns are also consistent with greater selection by the market of the least productive and profitable businesses after foreign competition was increased, access to subsidized credit was reduced, and dismissal costs were lowered following the reforms.

Before proceeding, it is useful to emphasize that the welfare implications (and even the productivity implications) are complex in this context with imperfect competition. Our paper is intended to be a contribution on characterizing the positive implications of market reform rather than the normative implications. There are several interesting complicating factors in considering welfare implications. For one, the market power of firms may derive from economic fundamentals or from institutional factors. For example, it may be that market power derives from product differentiation by each producer and that markets are best characterized by monopolistic competition. The exploitation of market power in this context by firms still generates a welfare loss with prices being above marginal cost, but even in the absence of markups substantial price heterogeneity across firms would still be a feature of a first-best equilibrium. Alternatively (or in addition), market power may derive from institutional barriers (e.g., trade restrictions). Simple intuition suggests that elimination of such barriers will improve welfare, but even here one should be cautious given potential second-best considerations. Another related complicated factor is that market power may play an important role in product and process innovations that lead to technological progress. In some creative-destruction models of innovation and growth (e.g., Aghion and Howitt (1992)), market power plays an important role for innovators in an environment in which there are fixed costs of innovation. We do not have much to say directly about this latter class of models since we do not directly investigate the role of product and process innovation. Part of the reason for this is that our empirical focus is on operating plants in manufacturing (not R\&D facilities). Our analysis has more to say about heterogeneity resulting from differences in adoption rather than innovation. However, a long standing issue in the empirical innovation literature is how much innovation occurs in R\&D facilities and how much occurs on the factory floor.

The rest of the paper proceeds as follows. Section 2 describes the Colombian context and the market reforms undertaken during the period of study. Section 3 describes the unique data we use in this analysis. Section 4 describes our methodology for estimating plant-level total factor productivity and demand shocks, and presents the results of these estimations. Section 5 describes basic patterns of productivity, demand, and prices in terms of dispersion and persistence. Section 6 examines the relations between efficiency and demand, on the one hand, and the allocation of activity, on the other hand, both before and 
after the reforms. Section 7 provides concluding remarks.

\section{Market Reforms in Colombia}

In 1990, the administration of President Cesar Gaviria conceived a comprehensive reform package, which included not only measures to modernize the state and liberalize markets but also a constitutional reform. In contrast to the experience in many reformist countries, there was no underlying economic crisis preceding the reform in Colombia. Rather, ample social and political unrest were the catalysts for institutional change (see, e.g., Edwards (2001)). Structural reforms to remove distortions from product and factor markets were introduced in parallel with constitutional changes to political institutions as part of a wider effort to control internal strife associated with violent activities of both illicit drug cartels and guerrilla groups. The absence of an economic crisis meant that there was no clear consensus for the need of market-oriented reforms, but at the same time good economic conditions were initially an asset as distributive conflict was addressed by elaborate resource transfer schemes (see, e.g. Kugler and Rosenthal (2003)). However, the inability to reconcile market oriented reforms with the continued and pervasive need for redistribution to compensate losers meant that by 1993 the spurt of reform of the early nineties came to a halt. Although there was no reversal of reforms, Colombia did not make additional progress in terms of further removing distortions while many other countries in Latin America, and around the world, actually deepened reform efforts (see, e.g., Burki and Perry (1997)). The fact that the structural reform process in Colombia was a one-off phenomenon aids our identification strategy in trying to assess its impact on the relation between reallocation and productivity.

Before Gaviria's administration, the government of President Virgilio Barco made some partial progress in trade liberalization but did not gain any significant ground in removing other distortions. The gradual decrease in tariffs initiated by Barco was accelerated by Gaviria after June 1991. By the end of 1991, nominal protection reached $14.4 \%$ and effective protection $26.6 \%$, down from $62.5 \%$ a year earlier, while $99.9 \%$ of items were moved to the free import regime. These measures clearly generated unrest among the owners of capital, who faced lower profit margins after trade liberalization due to increased foreign competition. The impact from market penetration by foreign exporters, and by foreign investors as pointed out below, on the market participation of domestic businesses in product markets was mitigated by more favorable conditions in factor markets, which lowered both capital and labor costs. In labor markets, Law 50 of December 1990 promoted the flexibilization of contracts and reduced labor costs by between $60 \%$ and $80 \%$ (see, e.g., Kugler $(1999,2004)$ ) . In 1990, the government also tried to introduce changes in the social security system as part of the labor reform package, but Congress forced an independent process to reform pension provision. The opposition to the original reform plan by the Executive stemmed partly from the proposal to lower labor costs by reducing employer's contributions. Later during the Gaviria administration, the execu- 
tive compromised with Congress by passing Law 100 in 1993. Although Law 100 allowed for voluntary individual conversion from a pay-as-you-go system to a fully-funded system with accounts, this law also introduced a mandatory hike in employer and employee contributions up to $13.5 \%$ of salaries, of which $75 \%$ was paid by employers (see, e.g., Kugler and Kugler (2003)).

A number of measures also reduced frictions in financial markets. In 1990, Law 45 was introduced with the goal of reducing state control and ownership concentration in the banking sector. Interest rate ceilings were eliminated and required reserves were reduced. At the same time, supervision was reinforced in line with the Basle Accords for capitalization requirements, though there were no requirements for banks to invest in government securities. Law 9 of 1991 established the abolition of exchange controls eliminating the monopoly of the central bank on foreign exchange transactions and lowering substantially the extent of capital controls. Finally, Resolution 49 of 1991 eliminated restrictions to foreign direct investment. This resolution established national treatment of foreign enterprises and eliminated limits on the transfer of profits abroad as well as bureaucratic procedures requiring the approval of individual projects (see, e.g., Kugler (2000)). This measure not only facilitated capital inflows across all sectors, but also induced entry of foreign banks increasing competition in the financial sector, thereby yielding lower intermediation costs.

After the end of Gaviria's term, in 1994 President Ernesto Samper gained power on a platform partially based on opposition to market institutions. ${ }^{4}$ While the new government was unsuccessful in terms of dismantling existing reforms, the coalition supporting the new government managed to bring the momentum for additional reforms to a halt.

Overall, though, the reform process was relatively smooth and successful in transforming a highly distorted economy into one burdened with many fewer frictions. Trade liberalization and the removal of FDI restrictions were aimed at increasing competition and shifting production away from low- and towards high-productivity businesses. In addition, the liberalization of factor markets had the purpose of facilitating reallocation in the economy after the structural reform process. If the goal of inducing productivity-enhancing reallocation was achieved, its success should be reflected in different patterns of industrial dynamics between the 1980's and the 1990's, with market allocation being driven to a large extent by productivity rather than profitability in the latter period. In the following sections, we investigate whether this is the case.

\section{Data Description}

Our data come from the Colombian Annual Manufacturers Survey (AMS) for the years 1982 to 1998. The AMS is an unbalanced panel of Colombian plants with more than 10 employees, or sales above a certain limit (around US\$35,000

\footnotetext{
${ }^{4}$ Note that the Colombian electoral system rules out re-election.
} 
in 1998). ${ }^{5}$ The AMS includes information for each plant on: value of output and prices charged for each product manufactured; overall cost and prices paid for each material used in the production process; energy consumption in physical units and energy prices; production and non-production number of workers and payroll; and book values of equipment and structures. The dataset also provides information on plant location as well as industry classification codes (5 digits CIIU).

Our aim in this paper is to estimate and describe the behavior of productivity and demand shocks in Colombia during the pre- and post-reform periods and to document how reallocation contributed to productivity and demand increases during the period of study and, especially, whether the relation changed after the reforms. To this end, we estimate total factor productivity (TFP) values for each plant using a capital-labor-materials-energy (KLEM) production function and demand shock values for each plant using a standard inverse-demand function. To estimate production and inverse-demand equations, we need to construct physical quantities and prices of output and inputs, capital stock series, and total labor hours.

\subsection{Plant-level Price Indices}

With the rich information on prices collected in the AMS, we can construct plant-level price indices for output, materials, and energy. This represents an enormous advantage with respect to other sources of data, as the use of more aggregate price deflators is a common source of measurement error, due to plantspecific demand shocks. Prices of output and materials are constructed using Tornqvist indices. For a composite of products or materials $i$ of each plant $j$ at time $t$ are constructed these Tornqvist indices are the weighted average of the growth in prices for all individual products or materials $h$ generated by the plant. This weighted average is given by:

$$
\Delta P_{i j t}=\sum_{h=1}^{H} \bar{s}_{h j t} \Delta \ln \left(P_{h j t}\right)
$$

where $i=Y, M$, i.e., output or materials,

$$
\Delta \ln \left(P_{h j t}\right)=\ln P_{h j t}-\ln P_{h j t-1},
$$

and

$$
\bar{s}_{h j t}=\frac{s_{h j t}+s_{h j t-1}}{2}
$$

\footnotetext{
${ }^{5}$ In the Appendix, we describe the methodology used to generate longitudinal linkages that allow following plants over time. As explained in the Appendix, over the period of study the AMS underwent changes in the sampling and labeling of plants, which require very involved work to generate these linkages and reduce spurious measurement of entry and exit of plants.
} 
and $P_{h j t}$ and $P_{h j-1}$ are the prices charged for product $h$, or paid for material $h$, by plant $j$ at time $t$ and $t-1$, and $s_{h t}$ and $s_{h t-1}$ are the shares of product $h$ in plant $j$ 's total production, or the shares of material $h$ in the total value of plant $j$ 's materials purchases, for years $t$ and $t-1 .^{6}$ The indices for the levels of output (or material) prices for each plant $j$ are then constructed using the weighted average of the growth of prices and fixing 1982 as the base year:

$$
\ln P_{j t}=\ln P_{i j t-1}+\Delta P_{i j t}
$$

for $t>1982$, where $P_{j 1982}=100$, and where the price levels are then simply obtained by applying an exponential function to the natural log of prices, $P_{i j t}=$ $\exp ^{\ln P_{i j t}} .^{7}$

\subsection{Capital Stock Series}

Given prices for materials and output, the quantities of materials and output are constructed by dividing the cost of materials and value of output by the corresponding prices. Quantities of energy consumption are directly reported by the plant. In addition, we need capital stocks to estimate a KLEM production function.

The plant capital stock is constructed recursively on the basis of the expression:

$$
K_{j t}=(1-\delta) K_{j t-1}+\frac{I_{j t}}{D_{t}}
$$

for all $t$ such that $K_{j t-1}>0$, where $I_{j t}$ is gross investment, $\delta$ is the depreciation rate and $D_{t}$ is a deflator for gross capital formation. Our measure of $D_{t}$ is the implicit deflator for capital formation from the input-output matrices for years 1991-1994, and from the output utilization matrices for later years. We use the "observed" depreciation rates calculated in Pombo (1999) at the 3-digit sectoral level, which range between $8.7 \%$ and $17.7 \%$ for machinery and between $2.4 \%$ and $9.8 \%$ for buildings.

Gross investment is generated from the information on fixed assets reported by each plant, using the expression:

$$
I_{j t}=K_{j t}^{N F}-K_{j t}^{N I}+d_{j t}-\pi_{j t}^{A}
$$

\footnotetext{
${ }^{6}$ The distribution of the weighted average of the growth of prices has large outliers, especially at the left side of the distribution. In particular, the distribution shows negative growth rates of $100 \%$ and more. In a country like Colombia, with inflation around 20\%, negative growth rates of these magnitudes seem implausible. For this reason, we trim the $1 \%$ tails at both ends of the distribution as well as any observation with a negative growth rate of prices of more than $50 \%$.

${ }^{7}$ Given the recursive method used to construct the price indices and the fact that we do not have plant-level information for product and material prices for the years before plants enter the sample, we impute product and material prices for each plant with missing values by using the average prices in their sector, location, and year. When the information is not available by location, we inpute the national average in the sector for that year.
} 
where $K_{j t}^{N F}$ is the reported value of fixed assets by plant $j$ at the end of year $t$, $K_{j t}^{N I}$ is the reported value of fixed assets reported by plant $j$ at the start of year $t, d_{j t}$ is the depreciation reported by plant $j$ at the end of year $t$, and $\pi_{i t}^{A}$ is the reported inflation adjustment to fixed asset value by plant $j$ at the end of year $t$ (only relevant since 1995, the first year in which plants were required by law to consider this component in their calculations of end-of-year fixed assets).

The capital stock series is initialized at the year the plant enters the sample, $t_{0}$. To obtain the initial value, we use the equation:

$$
K_{i t_{0}}=\frac{K_{i t_{0}}^{N I}}{0.5 D_{t_{0}}+0.5 D_{t_{0}-1}}
$$

where $K_{j t_{0}}^{N I}$ is the first reported nominal capital stock at the beginning of the year. In constructing the capital stock series we include equipment, machinery, buildings and structures, while excluding vehicles and land.

\subsection{Total Labor Hours}

Finally, we construct a labor measure as total hours of employment. Since the AMS does not have data on production and non-production worker hours, we construct a measure of total employment hours at time $t$ for sector $G(j)$, to which plant $j$ belongs, as,

$$
h_{G(j) t}=\frac{\operatorname{earnings}_{G(j) t}}{w_{G(j) t}},
$$

where $w_{G(j) t}$ is a measure of sectoral wages at the 3 -digit level from the Monthly Manufacturing Survey, and earnings ${ }_{G(j) t}$ is a measure of earnings per worker constructed from our data as

$$
\text { earnings }_{G(j) t}=\frac{\sum_{j \in G} \text { payroll }_{j t}}{\sum_{j \in G} l_{j t}}
$$

Then, the total employment hours measure is constructed as, ${ }^{8}$

$$
L_{j t}=l_{j t} h_{G(j) t},
$$

where $l_{j t}$ is the total number of employees in firm $j$ at time $t$.

\footnotetext{
${ }^{8}$ While we observe total employment at the plant-level, we do not observe total hours. Our method is to impute total hours per worker for plant $j$ using the average for plants in the same industry as plant $j$. A large share of the variation in total employment hours stems from total employment variation.
} 


\subsection{Descriptive Statistics}

Table 1 presents descriptive statistics of the quantity and price variables just described, for the pre- and post-reform periods, by continuing, entering or exiting status. The table reports entry and exit rates of $9.8 \%$ and $8.7 \%$ during the pre-reform period, but a lower entry rate of $8.4 \%$ and a higher exit rate of $10.7 \%$ during the post-reform period. ${ }^{9}$ The quantity variables are expressed in logs, while the prices are relative to a yearly producer price index to discount inflation. Output increased between the pre- and post-reform periods . Similarly, except for labor, input use increased between the pre- and post-reform periods. In particular, the table shows that capital, materials and energy use increased between the pre- and post-reform periods especially for incumbents and entrants. On the other hand, labor use decreased between the two periods for entering and exiting plants. Relative prices of output and materials prices declined between the pre- and post-reform periods for all plants. ${ }^{10}$

Table 2 reports simple correlations of the various variables reported in Table 1 , which display by and large the expected patterns. Output is positively correlated with all inputs, negatively correlated with its own price, and negatively but weakly correlated with energy and materials prices. Inputs are positively correlated with each other. All inputs are negatively correlated with energy prices, except for materials. All inputs are negatively correlated with materials prices, except for labor. Energy and materials use are negatively correlated with their own prices. Also, as expected, output prices are positively correlated with materials prices, and negatively but weakly correlated with energy prices. Finally, energy and materials prices are weakly and negatively correlated.

In the next section, we use these variables to estimate the production function and inverse-demand equation.

\section{Estimation of TFP and Demand Shocks}

We estimate total factor productivity with plant-level physical output data, using downstream demand to instrument inputs. In turn, we estimate demand shocks and mark-ups with plant-level price data, using TFP to instrument for output in the inverse-demand equation.

\footnotetext{
${ }^{9}$ These entry and exit rates are lower than those reported for the U.S. and other OECD countries (Davis, Haltiwanger, and Schuh (1996)). Given that the Colombian economy is subject to greater rigidities, one may indeed expect lower entry and exit rates in the Colombian context (see, e.g., Tybout (2000) for a discussion of this issue).

${ }^{10}$ Caution needs to be used in interpreting the aggregate (mean) relative prices in this context since the relative price at the micro level is the log difference between the plant-level price and the log of the aggregate PPI. On an an appropriately output weighted basis, the mean of this relative price measure should be close to zero in all periods (or one in levels) since the PPI is dominated by manufacturing industries. The larger difference with respect to PPI in the post-reform period reflects that the growth of manufacturing prices fell more rapidly than that of other prices in the economy, possibly due to the fact that external competition introduced by the reforms affected the manufacturing sector more than others.
} 


\subsection{TFP Estimation}

We estimate total factor productivity for each establishment as the residual from a capital-labor-energy-materials (KLEM) production function:

$$
Y_{j t}=K_{j t}^{\alpha} L_{j t}^{\beta} E_{j t}^{\gamma} M_{j t}^{\phi} V_{j t},
$$

where, $Y_{j t}$ is output, $K_{j t}$ is capital, $L_{j t}$ is total employment hours, $E_{j t}$ is energy consumption, $M_{j t}$ are materials, and $V_{j t}$ is a productivity shock. We estimate this production function in logs,

$$
\log Y_{j t}=\alpha \log K_{j t}+\beta \log L_{j t}+\gamma \log E_{j t}+\phi \log M_{j t}+\log V_{j t},
$$

so that our total factor productivity measure is estimated as:

$$
T F P_{j t}=\log Y_{j t}-\widehat{\alpha} \log K_{j t}-\widehat{\beta} \log L_{j t}-\widehat{\gamma} \log E_{j t}-\widehat{\phi} \log M_{j t} .
$$

where $\widehat{\alpha}, \widehat{\beta}, \widehat{\gamma}$, and $\widehat{\phi}$ are the estimated factor elasticities for capital, labor, energy, and materials. In addition, we estimate a value-added production function with only capital and employment to provide a benchmark of comparison with other studies. Whether we estimate value-added or KLEM specifications, using OLS to estimate the production function is likely to generate biased estimates of factor elasticities as productivity shocks are probably correlated with capital, labor, energy, and materials. For example, the introduction of capital-biased technologies is likely to be associated with greater use of capital and energy and with less employment.

We deal with this omitted variable bias by using demand-shift instruments which are correlated with input use but uncorrelated with productivity shocks. In particular, we construct Shea (1993) and Syverson (2003) type instruments by selecting industries whose output fluctuations are likely to function as approximately exogenous demand shocks for other industries. The instruments are total output measures in downstream industries, or combinations of downstream industries, that satisfy two conditions: (1) they buy a large enough fraction of the output generated by the upstream industry (i.e., the relevance condition), and (2) their purchases from the output industry are a relatively small share of their costs (i.e., the exogeneity condition). The latter condition is important to ensure that the upstream industry is not affecting the downstream industry, so that the instrument - downstream demand - is uncorrelated with productivity shocks upstream. The first condition is important to ensure relevance of the instruments, i.e., strong correlations between the instruments and use of inputs upstream. Following Shea (1993), we use the input-output matrix for each year to construct instruments for the equivalent of two-digit industries in the U.S. ${ }^{11}$ For the instruments to meet the two criteria above, we

\footnotetext{
${ }^{11}$ We use input-output matrices from the national accounts for the pre-1994 period. For the later years, a new methodology was put in place for the national accounts, and input-output matrices were replaced by output-use and output-supply matrices. For these later years, we rely on output-use matrices to determine cost and sales shares, and on output-supply matrices to determine sectoral output. It is also important to note that input-output matrices do not use ISIC codes to classify industries. The level at which we could create concordance is close to the 2-digits ISIC codes.
} 
impose that: (1) the demand share of the downstream industry for upstream production has to exceed $15 \%$, and (2) the cost share of the upstream industry products in the downstream's total costs is less than 15 percent. ${ }^{12}$ We also use one- and two-period lags of the demand shifters. The rationale for doing this is that some factors, such as capital and labor, may face non-linear adjustment costs and irreversibilities, so that demand shifts may take various periods to affect factor utilization. In addition, we use regional government expenditures, excluding government investment, in the region where the plant is located as an instrument to capture shifts in local demand. ${ }^{13}$ We regard this instrument as particularly relevant to identify the coefficient on labor, given that labor markets in Colombia are largely region-specific. Finally, we use energy and materials prices as instruments, which are negatively correlated to energy consumption and use of materials, but likely to be uncorrelated with productivity shocks.

Table 3 reports results for the value-added specification with only capital and employment and for the KLEM specification of the production function. Column (1) reports the OLS results from the estimation of the value-added specification. The results show an elasticity for capital of about 0.3 and an elasticity for employment of about 0.74 , which are in line with other studies. The problem with this specification in terms of estimating total factor productivity is, however, that it imposes implausible restrictions in terms of the elasticity of output to energy and materials. For this reason, we estimate a KLEM specification which uses physical output in the left-hand side and also includes energy and materials as inputs. Furthermore, the inclusion of energy can help account for different levels of capital utilization, under the plausible as-

\footnotetext{
${ }^{12}$ While Shea (1997) uses a criterion of exogeneity based on the ratio of demand share to cost share (i.e., this ratio being less than 3), our criterion is based on absolute cost shares (i.e., having a cost share of less than 15\%). This absolute criterion is more binding than the ratio criterion for downstream industries that represent large demand shares, and less binding for other dowsntream industries. Using the above criteria, adding exports to the downstream demand set and also aggregrating downstream industries to two or three industries to meet the greater than $15 \%$ threshold, we obtain instruments for 8 of the 12 upstream industries (i.e., Drinks and Beverages, Wood, Food, Textiles, Oil, Paper, Chemicals and Rubber, and Glass and other non-metallic products). The 4 sectors without demand-shift instruments are Tobacco, which makes up a very low share of sales for other industries; Metals and Machinery, which comprise too high a share of costs when the sales share is high enough; and Other Manufacturing, a category that includes widely different and changing types of goods, for which costs and sales shares are difficult to define in a meaningful and consistent manner.

${ }^{13}$ There may be a common component in technology shocks, although given the enormous heterogeneity across plants the idiosyncratic component dominates. However, this common component of technology shocks is unlikely to be correlated with regional government expenditures, since it takes time for government expenditures to respond to changes in the local economy. Moreover, although certain types of government expenses can constitute aggregate productivity shocks (e.g., construction of road ways), these are likely to show up in the investment side of the government accounts. This is the reason why we use regional government expenditures, excluding government investment, as an instrument. It is also worth emphasizing that results in the remainder of the paper are robust changing this instrument to total regional government expenditure (which includes government investment), and even to state GDP. That is, we obtain virtually the same results for the estimation of the production functions and all the results that depend upon our TFP and demand shock estimates. Most results are also robust to the exclusion of this instrument but, as we expected, the coefficient of labor hours is very imprecisely estimated in this case, and even has the wrong sign.
} 
sumption that the latter is positively correlated with the use of energy. Column (2) presents the OLS results from the estimation of the KLEM specification. ${ }^{14}$ As expected, factor elasticities for capital and labor become smaller, as energy and materials are allowed to impact output in a nonlinear fashion. The results now suggest elasticities for capital, labor, energy, and materials of about 0.08 , $0.24,0.12$, and 0.59 , respectively.

However, as pointed out above, these elasticities are likely to be biased if productivity shocks are correlated with input use. Columns (3) and (4) of Table 3 present results using 2SLS estimation, which rely on the current and lagged demand-shift instrument, regional government expenditures, and input prices. Even if we think these instruments are weakly correlated with productivity shocks, large biases could be introduced when using IV estimation if instruments are weakly correlated with the inputs. ${ }^{15}$ To check whether inputs are highly and significantly correlated with the instruments, Table 4 reports results for the first-stages of the inputs on the various instruments. The results suggest use of energy and materials increases significantly with downstream demand, but employment hours decrease significantly with downstream demand. Moreover, capital, energy use and materials are negatively and significantly correlated with the one-period lag of downstream demand, and all inputs are positively and significantly correlated with the two-period lag of downstream demand. Regional government expenditures are positively and strongly correlated with capital and labor and negatively correlated with materials and energy consumption. Also, as expected, materials and energy prices significantly reduce energy consumption and use of materials and capital, respectively. Given that we are considering instrument relevance with multiple endogenous regressors, we report the partial $R^{2}$ measures suggested by Shea (1997) for the first-stages, which capture the correlation between an endogenous regressor and the instruments after taking away the correlation between that particular regressor with all other endogenous regressors. ${ }^{16}$ The partial $R^{2}$ 's for capital, employment

\footnotetext{
${ }^{14}$ The increase in the number of observations from Column (1) to Column (2) (and also from Column (3) to Column (4)) is due the fact that Column (1) uses the log of value-added while Column (2) uses the log of physical output as the dependent variable. Observations are lost in the value added specification because the level of value added takes negative values in some cases.

${ }^{15}$ We also considered longer lags and exponential terms of the demand-shifters as well as other measures of regional shocks, including total regional government expernditures and state GDP. The results reported here are largely robust to these changes in the list of instruments. To select our baseline instruments, we tested for overidentifying restrictions using a variant of Basmann's (1960) test, where we estimate a regression of the production function residual on the instruments. While lags of more than two periods and exponential terms of the demand shifters turn out to be significant in these regressions, the rest of our instruments are individually and jointly insignificant. We restrict our instrument list to include those instruments which are not jointly significant in this regression. Although regional government expenditures (excluding government investment), total regional government expenditures, and state GDP all turn out to be insignificant in this regressions, we rely on regional government expenditures (excluding investment) for the reasons pointed out in Footnote 13.

${ }^{16}$ The standard $R^{2}$ simply reports the square of the sample correlation coefficient between $I_{j t}$ and $\hat{I}_{j t}$, where $I=K, L, E, M$ and $\hat{I}_{j t}$ are the predicted values of the inputs from a regression of $I_{j t}$ on the instruments. The partial $R^{2}$ reports the square of the sample correlation
} 
hours, energy, and materials in the KLEM specification are 0.1276, 0.139, 0.231, and 0.324 , respectively, and 0.2563 and 0.1324 for capital and employment in the value-added specification, showing that the relevant instruments for each input can explain a substantial fraction of the variation in the use of that input.

The IV results for the value-added specification in Column (3) of Table 3 show larger capital and employment elasticities relative to the OLS estimated elasticities. The results in Column (4) of Table 3 also show larger elasticities for capital and energy, but smaller elasticities for labor hours and materials, when inputs are instrumented. ${ }^{17}$ The results from the value-added and KLEM specifications, thus, indicate that productivity shocks during the period of study are positively correlated with hours and materials and negatively correlated with capital, employment and energy, suggesting the adoption of hour-intensive and energy-saving technologies in Colombia during the 1980's and 1990's.

\subsection{Estimation of Demand Shocks}

While productivity is likely one of the crucial components of profitability, other components of profitability are also probably important determinants of reallocation. For example, even if plants are highly productive, they may be forced to reduce their market shares if faced with large negative demand shocks. We capture the demand component of profitability by estimating establishment-level demand shocks as the residual of the following inverse-demand equation: ${ }^{18}$

$$
P_{j t}=Y_{j t}^{-\varepsilon} D_{j t},
$$

where $D_{j t}$ is a demand shock faced by firm $j$ at time $t$ and $-\varepsilon$ is the inverse of the elasticity of demand and $1+\varepsilon$ is the mark-up. We estimate this inverse-demand function in logs,

$$
\log P_{j t}=-\varepsilon \log Y_{j t}+\log D_{j t},
$$

and our demand shock measure is estimated as the residual from this regression,

$$
d_{j t}=\log \widehat{D}_{j t}=\log P_{j t}+\widehat{\varepsilon} \log Y_{j t},
$$

where $-\widehat{\varepsilon}$ is an inverse measure of the elasticity of demand. Using OLS to estimate the inverse-demand function is likely to generate an upwardly biased estimate of demand elasticities because demand shocks are positively correlated

coefficient between $g_{j t}$ and $\widehat{g}_{j t}$, where $g_{j t}$ are the residuals from an OLS regression of $I_{j t}$ on all other inputs $I_{1 j t}$ and $\widehat{g}_{j t}$ are the residuals from an OLS regression of $\hat{I}_{j t}$ on the predicted values of all other inputs $\hat{I}_{1 j t}$.

${ }^{17}$ The value-added specification ignores changes in labor utilization. If technology shocks are negatively correlated with employment but positively correlated with labor hours, this would explain why the elasticity of labor increases when the value-added specification is instrumented, while the elasticity of labor hours falls when the KLEM specification is instrumented.

${ }^{18}$ There are other important components of profitability that we do not measure, such as access to credit markets. 
to both output and prices, so that $\widehat{\varepsilon}$ will be smaller in absolute value than the true $\varepsilon$. To eliminate the upward bias in our estimates of demand elasticities, we propose using TFP as an instrument for $Y_{j t}$ since TFP is positively correlated with output (by construction) but unlikely to be correlated with demand shocks.

Table 5 reports the results of the inverse-demand equations using both OLS and IV estimation. Columns (1)-(3) present OLS results of inverse-demand equations, some of which impose the same elasticity while others allow different elasticities for the pre- and post-reform periods. Columns (4)-(6) present equivalent 2SLS results. ${ }^{19}$ Column (1), which presents OLS results when imposing the same elasticity before and after the reforms, suggests a large elasticity of 11.05 for the entire period of study. The results in Column (2) which allow for different elasticities before and after the reforms suggest demand elasticities of 11.66 and 10.94 during the pre- and post-reform periods, respectively. ${ }^{20}$ By contrast, the results in Column (3), which allow for different intercepts and different elasticities after the reforms, show elasticities of 22.37 and 7.37 during the pre- and post-reform periods, but higher demand after the reforms. As indicated, however, caution needs to be exercised in interpreting these as elasticities since these coefficients capture the fact that higher demand implies a positive correlation between output and prices.

The 2SLS results, which use TFP as an instrument for output, indeed show much lower elasticities. ${ }^{21}$ The results in Column (4) show a demand elasticity of 2.28, while the results in Column (5) show a demand elasticity of 2.24 during the pre-reform period and of 2.3 during the post-reform period. By contrast, allowing for different intercepts and elasticities before and after the reforms suggests elasticities of 3.17 before the reforms and of 1.88 after the reforms, but higher demand after the reforms at given price levels. ${ }^{22}$ The last three columns

\footnotetext{
${ }^{19}$ The sample size is larger in this table than in Table 3 because the estimations in Table 3 require information on the instruments used for estimating the production function, while demand estimations only require information on output prices, physical output, and TFP estimates.

${ }^{20}$ The pre-reform elasticity is calculted as the inverse of the estimated physical output coefficient. And, the post-reform elasticity is calculted as the inverse of the sum of the estimated physical output coefficient and the estimated coefficient of physical output interacted with the post-reform dummy.

${ }^{21}$ The negative R-squares for the 2SLS are not surprising and should not be viewed as alarming. Output and the demand shocks are highly positively correlated (this is the entire reason for using 2 SLS rather than OLS). Using the simple inverse-demand equation, the variance of prices will be equal to terms involving the variance of output, the variance of demand shocks and a term that depends negatively on the covariance of output and demand shocks (given that the demand elasticity is negative). Thus, the variance of demand shocks will exceed the variance of prices and, hence, the negative R-squares.

${ }^{22}$ Robustness analysis suggests that while it is important to use a TFP measure as an instrument in the demand equations for output (i.e., elasticities are quite different between OLS and 2SLS in demand equation), it matters much less whether the TFP used is from OLS or 2SLS estimation of production equation. This reduces concerns about sensitivity of results to instrument selection for production equations. In addition, we considered energy and materials prices as instruments for physical output in the inverse-demand equations and we find that the results are very similar whether we use TFP alone or TFP and energy and materials prices as instruments.
} 
in Table 5 report high total and partial $R^{2}{ }^{\prime} \mathrm{s}^{23}$ The partial $R^{2}$ 's for physical output and physical output interacted with the post-reform dummy on TFP, a post-reform dummy, and TFP interacted with the post-reform dummy are of 0.427 and 0.4621 , indicating relevance of the instruments. These results suggest quantities responded less to changes in prices but overall demand was higher after the reforms. Increased demand after reforms may be explained by scale effects generated by trade liberalization measures and by the downward shift in average production costs induced by factor market reforms.

\section{TFP, Demand, and Prices Before and After the Reforms}

In this section we rely on the TFP and demand shock measures estimated in the last two sections as well as on output prices to document differences in the productivity and demand components of profitability in Colombia during the 1980's and 1990's in terms of heterogeneity and persistence. We are, for example, interested in documenting whether productivity is as heterogeneous and persistent in Colombia as it is in other countries.

Before turning to these issues, however, we report in Table 6 basic descriptive statistics of TFP, demand shocks and output prices for the periods before and after the reforms. The table shows an increase in the simple means of total factor productivity and our demand shock measure, but a decrease in the mean of output prices. Caution needs to be used in interpreting these simple averages. For TFP, as we emphasize later aggregate TFP can be decomposed into a term based upon the simple (unweighted) average and a covariance term reflecting the relationship between market share and TFP. The latter can be interpreted as an index of the efficiency of the allocation of resources and as we show later is very important in Colombia. With respect to relative prices and demand shocks, note that the average price is the average price of plant output relative to the PPI. The average demand shock is the average of the demand shocks constructed from a micro model of relative prices across plants. On the other hand, the table shows a substantial increase in the dispersion of TFP, demand shocks, and output prices. The standard deviations of TFP, demand shocks and prices increased from 0.68 to 0.91 , from 0.78 to 0.88 , and from 0.44 to 0.74 , respectively. In addition, as expected, Table 6 shows a negative correlation between prices and TFP and output, and a positive correlation between demand shocks and prices both before and after the reforms, though the correlations are stronger after the reforms. By contrast, TFP and demand shocks are positively correlated during the pre-reform period but negatively correlated

\footnotetext{
${ }^{23}$ The total $R^{2}$ simply reports the square of the sample correlation coefficient between $Y_{j t}$ and $\widehat{Y}_{j t}$, where $\widehat{Y}_{j t}$ is the predicted value of output from a regression of $Y_{j t}$ on the instruments. The partial $R^{2}$ reports the square of the sample correlation coefficient between $u_{j t}$ and $\widehat{u}_{j t}$, where $u_{j t}$ are the residuals from an OLS regressions of $Y_{j t}$ on $Y_{j t} \times$ Post - reform and $\widehat{u}_{j t}$ are the residuals from an OLS regression of the predicted value of $Y_{j t}$ on the predicted value of the other regressors of the demand equation.
} 
after the reforms. This correlation points to the effects of trade reform: after trade liberalization, producers in sectors most exposed to import competition will simultaneously increase productivity and lose demand. In contrast, manufacturers in sectors least exposed to import competition will have relatively less incentives for productivity enhancement and will less likely face a drop in demand. In addition, the table shows that firms facing higher demand and productivity shocks produce more output, both before and after reforms. However, while the relation between output and productivity becomes stronger after the reforms, the relation between output and demand becomes weaker. This correlation suggests, again, that the reforms were successful in strengthening the link between a business's performance and its productivity. Moreover, this table shows that not only do more productive firms increase production after the reforms, but they also increase their share in the market. This points to the increased importance of productivity-enhancing reallocation after the reforms, which we document in Section 6.

\subsection{Heterogeneity}

Previous evidence for the US suggests a pattern of evolving common productivity and prices among heterogeneous plants (Baily, Hulten and Campbell (1992); Foster, Haltiwanger and Krizan (2002); Foster, Haltiwanger and Syverson (2003); Supina and Roberts (1996)). Like in the U.S., dispersion measures in Table 6 suggest much heterogeneity in productivity and prices across Colombian plants. Figures 1-3 show the evolution of dispersion measures of TFP, demand shocks and output prices over the entire period of study. ${ }^{24}$ The figures show large percentage increases in the dispersion of productivity and prices over the last two decades. In particular, figures 1 and 3 shows large rises in the dispersion of productivity and prices of entering and exiting plants after 1990, and a constant increase in the dispersion of productivity and output prices of continuing plants throughout the entire period. By contrast, Figure 2 shows a much smaller percentage increase in the dispersion of demand over the last two decades. The greater heterogeneity in productivity is consistent with greater process experimentation across businesses after reforms, while the modest increase in the dispersion of demand is consistent increased competition, and also with modest increased experimentation in product variety across businesses.

Figures 4-6 show Kernel distributions of TFP, demand shocks and output prices for the pre- and post-reforms periods, which illustrate changes in higher moments of the distributions. The distributions display fatter tails (i.e., increased kurtosis) of the distributions of TFP, demand shocks and output prices after the reforms, suggesting that more firms were experiencing either positive or negative large shocks after the reforms.

\footnotetext{
${ }^{24}$ We have examined these patterns using alternative robust measures of dispersion (in particular, the 90-10 differential) and have found very similar patterns overall for TFP, prices and demand shocks.
} 


\subsection{Persistence}

To examine whether Colombian plants, like U.S. plants, are characterized by a large degree of persistence, we estimate $\mathrm{AR}(1)$ models for productivity, demand shocks and prices. Columns (1), (3) and (5) in Table 7 report the coefficients on the lags of productivity, demand and output prices for AR(1) models with year effects. Our estimates show a great deal of persistence of productivity, demand shocks and prices in Colombia, much greater than that found for the U.S. The results suggest that $67 \%$ of all plants continue with their initial productivity after 5 years, $93 \%$ of plants face the same demand shocks after 5 years, and $96 \%$ charge the same prices as 5 years ago. Studies for the U.S. find much lower degrees of persistence. For example, Bartelsman and Dhrymes (1998) find that after 5 years only about a third of all plants remain in the same productivity quintile. Foster, Haltiwanger and Syverson (2003) also find that about a third of plants remain in their original position in the productivity and price distributions after 5 years. In spite of the reforms increased competition after the reforms, the greater persistence in the Colombian context probably reflects continued presence of distortions in this economy.

Columns (2), (4), and (6) in Table 7 also report how the degree of persistence changes after the market reforms. The results suggest persistence in productivity and output prices increased after the reforms, while the persistence of demand shocks did not change. At first glance, this pattern might be surprising as one might conjecture that market reforms would lead to greater mobility in the distributions of efficiency, demand shocks, and prices. However, it is important to emphasize that these persistence measures are conditional on survival. Our results are consistent with increased weeding out of less productive plants, as reported in the next section, but lower mobility of the plants that do survive after the reforms.

\section{Productivity- and Profitability-Enhancing Re- allocation}

In this section, we examine whether the market reforms changed the allocation of activity in terms of productivity and demand factors. In particular, we are interested in whether increased competition as a result of the reform process induced reallocation from less to more productive plants and reduced the role of demand factors in the allocation of activity. Similarly, we are interested in whether increased competition as a result of the reforms increased productivity by making it more difficult for less productive plants to enter the market and survive. Different types of models have been proposed which can explain productivity-enhancing reallocation of this sort. In learning models (e.g., Jovanovic (1982), and Ericson and Pakes (1989)), experimentation generates differences in productivity and successful experimenters gain market share over unsuccessful ones. Similarly, vintage capital models can explain gains in market share of plants with newer vintages over those with older vintages. 
If more efficient plants can afford more frequent retooling, initial productivity differences would be exacerbated. Moreover, if trade liberalization and FDI increased competition in product markets after the reform process, this may have speeded up learning and productivity-enhancing reallocation. Similarly, if financial liberalization in 1992 improved access to credit markets, this may have provided access to better capital vintages and increased productivity-enhancing reallocation after the reforms.

\subsection{Productivity Growth and Reallocation}

We use a cross-sectional decomposition methodology, first introduced by Olley and Pakes (1996), to examine whether the allocation of activity in the economy has become more or less productivity-enhancing over our period of study. We conduct the following decomposition of aggregate TFP and total demand shocks, constructed from our estimates of plant-level TFP and demand:

$$
\begin{aligned}
T F P_{t} & =\overline{T F P}_{t}+\sum_{j=1}^{J}\left(f_{j t}-\overline{f_{t}}\right)\left(T F P_{j t}-\overline{T F P_{t}}\right) \\
d_{t} & =\bar{d}_{t}+\sum_{j=1}^{J}\left(f_{j t}-\bar{f}_{t}\right)\left(d_{j t}-\bar{d}_{t}\right)
\end{aligned}
$$

where $T F P_{t}$ and $d_{t}$ are aggregate total factor productivity and demand shock measures for a given 3-digit manufacturing sector in year $t$. These aggregate measures correspond to weighted averages of our plant-level measures TFP and demand shocks, where the weights are market shares (calculated as described below). $\overline{T F P}_{t}$ and $\bar{d}_{t}$ are the cross-sectional (unweighted) means of total factor productivity and demand shock measures across all plants in that sector in year $t, T F P_{j t}$ and $d_{j t}$ are total factor productivity and demand shock measures of plant $j$ at time $t$ estimated as described in Section $4, f_{j t}$ is the share or fraction of plant $j^{\prime} s$ output out of sectoral output at the 3-digit level in year $t$, and $\bar{f}_{t}$ is the cross-sectional unweighted mean of $f_{j t} .{ }^{25}$ The second term in this decomposition allows us to understand whether production is disproportionately located at high-productivity or high-demand plants. Moreover, by examining this decomposition over time we can learn whether the cross-sectional allocation of activity has changed in response to the market reforms. ${ }^{26}$

\footnotetext{
${ }^{25}$ This means that our focus here is on within sector allocation and reallocation rather than between sector allocation, for sectors defined at the 3-digit level. For measurement and conceptual reasons, comparisons of TFP and relative demand across sectors (in levels) are more problematic to interpret. Focusing on within sector allocation permits us to emphasize the degree to which market reforms have led to an improved allocation of activity across businesses due to higher competition. Nevertheless, we have also tried a decomposition using the shares or fraction of plant output out of total output. The results based on this alternative decomposition are similar to those reported below.

${ }^{26}$ An advantge of this cross-sectional method over methods that decompose changes in productivity over time, is that cross-sectional differences in productivity are more persistent
} 
Table 8 shows the cross-sectional decompositions for TFP and demand shock measures from 1982 to 1998. We report the results for the average 3-digit sector. Column (1) shows a positive trend in aggregate total factor productivity over the period of study. Columns (2) and (3) show the decomposition of aggregate productivity into the simple average and the cross-sectional correlation between market share and total factor productivity. In all years, aggregate productivity is largely accounted for by the allocation of activity to higher productivity businesses, as shown by the large fraction that the cross-term represents out of aggregate productivity. This stands in sharp contrast to results of similar exercises for the U.S., where the contribution of this term is only marginal (see Foster, Haltiwanger and Krizan (2001)). In a context in which the production possibilities frontier is not improving sharply over time, the allocation of activity seems to be the crucial factor accounting for the level of aggregate productivity.

The cross-sectional correlation between market share and total factor productivity remained roughly constant over the 1980's, with a slight decrease by the middle of the decade. By contrast, it increased sharply during the 1990's, most specially after 1993, once most reforms were fully implemented. This time-series pattern can be seen in Figure 7 and suggests that market share increasingly shifted towards more productive plants and away from less productive plants during the 1990's. In fact, while average productivity explains about $8.6 \%$ of aggregate productivity during the pre-reform period, it only explains about $5.5 \%$ of aggregate productivity during the post-reform period.

Columns (1)-(3) in Table 9 provide evidence of the statistical significance of the effects of reforms on the Olley-Pakes decomposition of TFP, just described. Each of these columns reports results of regressing one of the terms of the TFP decomposition on a post-reform dummy that takes a value of 1 in 1991-1998, and ISIC 3-digit sector controls, using data at the 3-digit level. Column (1) shows results using aggregate TFP (the weighted average of TFP using market shares as weights) as dependent variable. The results show a statistically significant increase in aggregate TFP after the reforms. Column (2) reports results of a regression of the simple average of TFP. These results show no significant change in the unweighted mean of TFP. Finally, column (3) reports results of a regression of the cross-sectional correlation between market share and TFP. The results show a significant increase of almost $50 \%$ (with respect to the magnitudes reported in Table 8) in the correlation between market share and TFP after the reforms. Thus, the post-reform period is characterized by a significant increase in the ability of highly productive firms to gain market share. ${ }^{27}$

The last three columns of Table 8 show the Olley-Pakes decomposition of our demand shock measure, since we are also interested in whether the reform

and less dominated by measurement error or transitory shocks. Another advantage is that this method does not rely on accurate measurement of entry and exit. The downside being, of course, that this decomposition does not allow charactererizing the role of entry and exit. We explore the latter in Section 6.2.

${ }^{27}$ As reform does not significantly change the simple average of TFP, rather than plant turnover what explains the changes in aggregate TFP is the reallocation from less productive to more productive incumbents. Indeed, below we document that on net the contribution of entry and exit to productivity rises only slightly post reform. 
process changed the role of demand factors in the allocation of activity. Column (4) shows a decreasing trend of aggregate demand shocks over the period of study, although the average plant actually perceived an increase in demand (column (5)). Moreover, in contrast to the results on productivity, Column (6) suggests that the concentration of activity in high demand plants became less important during the 1990's. Figure 8 shows the time-series pattern of this decomposition.

The statistical significance of the effects of reforms on the decomposition of demand shocks is analyzed in columns (4)-(6) of Table 9. As was the case for the decomposition of TFP, each of these columns presents the results of a regression of one of the components of the decomposition of demand on the post-reform dummy and sector controls, using data at the 3-digit sector level. The dependent variable in column (4) is the aggregate demand shock, in column (5) it is the simple average of plant-level demand shocks, and in column (6) it is the cross term of the decomposition. The results indicate a negative and statistically significant change in aggregate demand shocks after the reforms (column (4)), although the magnitude of the change is small relative to the magnitudes of aggregate demand shocks, as reported in Table 8. Nevertheless, the demand shocks faced by the average plant experience a positive and significant change with the reforms. The decline in aggregate demand shocks is explained by a decrease in the correlation between demand shocks and market share, which fell significantly after the reforms. These effects point to a decline in the relative importance of high demand in gaining market share.

Our results suggest that the packet of reforms, most likely through its components of trade liberalization, removal of FDI restrictions and liberalization of factor markets, contributed to raise productivity by improving the allocation of activity with higher market shares at high-productivity plants and lower market shares at low-productivity plants. At the same time, we find that, after the reforms, the allocation of activity was driven less by high demand plants commanding larger shares. This latter finding is consistent with the hypothesis that increased competition reduced the influence of demand factors (i.e., markets became more competitive) in the allocation of activity.

\subsection{Entry and Exit Effects}

Vintage capital models of industry dynamics suggest new firms are relatively more productive, as they receive the productivity associated with the latest vintage technology, and once they have entered the market their productivity remains constant over time unless hit by random shocks. Then, firms exit the market when the productivity relative to new entrants is below a certain threshold. However, aside from Foster, Haltiwanger and Syverson (2003) who find higher productivity of entering plants and lower productivity of exiting plants, the previous literature documents lower productivity of both entering and exiting relative to incumbent plants (see Bartelsman and Doms (2000)), a finding that is at odds with the vintage capital model. Using our estimates of TFP and demand shocks, we analyze this issue for the Colombian economy, and 
explore whether the market-oriented reforms changed how productive entering and exiting businesses are relative to incumbents.

Table 10 reports regressions of TFP, demand shocks, and prices on year dummies as well as on entry and exit dummies. The entry dummy takes a value of 1 for plant $j$ in period $t$ if the plant produced in year $t$ but not in $t-1$ . Conversely, the exit dummy takes a value of 1 for plant $j$ in period $t$ if plant $j$ produced in period $t$ but not in $t+1$. Column (1) in Table 10 shows that, consistent with the vintage capital hypothesis, productivity of entering plants is above and productivity of exiting plants below that of the average incumbent. Our results coincide with those in Foster, Haltiwanger, and Syverson (2003). Like theirs, our TFP estimation uses physical output rather than revenue, which avoids confounding price and productivity variations in measures of TFP. The results in Column (5) also show lower idiosyncratic demand for entering and exiting plants relative to the average incumbent, and the results in Column (9) show entrants and exiting plants charging higher prices than incumbents. While higher prices at exiting plants are consistent with their lower productivity, higher prices at entering plants might reflect their smaller scale or perhaps higher markups.

Since the reforms introduced during the 1990's are generally expected to increase competition, we also explore whether the productivity, demand and prices of entering and exiting plants relative to incumbents changed after the implementation of these reforms by interacting the entry and exit dummies with a post-reform dummy which takes the value of 1 for the period 1990-1998. The results in Column (2) of Table 10 show a much smaller differential entry effect on productivity after the reforms. That is, after the reforms, entering businesses had a smaller productivity advantage relative to incumbents in the year of entry. Lower adjustment costs due to less distorted factor markets appear to show a greater ability of surviving incumbents to catch-up with potentially highly productive entrants. First, they can retool more frequently to install latest vintage technologies. Second, this is consistent with increased layoffs of unproductive workers after the reduction in dismissal costs in 1990. Alternatively, there may have been increased market experimentation after the reforms so that the average entrant had lower initial productivity. This latter idea we explore further below.

On the other hand, the results suggest that productivity of exiting plants relative to incumbents fell substantially after the reforms. This pattern is consistent with increased exit of plants which may had been kept afloat by subsidized credit, relatively low taxes, and lack of international competition before 1990. On net, the contribution of entry and exit to overall productivity rises slightly after the reforms. Moreover, the results show that relative demand for entering and exiting plants did not change after the reforms. On the other hand, relative prices of both entering and exiting plants increased after the reforms.

We also examine learning effects by looking at the evolution of productivity, demand, and prices of plants over the first years they are in the market. The results in Column (3) of Table 10 , for the entire period, include one- and 
two-period lags of the entry dummies and one- and two-period leads of exit dummies, capturing plants that entered in $t-1$ and $t-2$ and plants that will exit in $t+1$ and $t+2$. The results show little evidence of learning prior to market reforms, as businesses do not appear to be more productive one or two years after entering than they were upon entrance. However, after market reforms there is evidence of substantial learning amongst entrants (Column (4)). As noted, the productivity advantage of entrants diminished after reforms, but the productivity advantage two years after entry increased substantially. This pattern is consistent with the hypothesis mentioned above of increased market experimentation by entrants after the reforms.

We also examine a number of other patterns in terms of entry and exit. It is interesting to note that there is evidence of a "shadow of death" effect: the negative productivity differential faced by exiting plants becomes stronger the closer to exiting the plant is. This effect grows stronger after reforms. We also find some evidence of "learning" in terms of demand and prices. In this context, we mean that entering plants appear to gain a greater demand/price advantage as time after entry grows. Column (7) and (11) show that, as time elapses since plant entry, the plant's relative demand grows and the prices it charges for its output fall. Columns (8) and (12) show greater learning effects in demand and prices after the reforms.

In short, the results suggest that market reforms yielded a more heterogenous group of entrants, but that conditional on survival the post-reform entrants contribute more to productivity . Subsidized credit prior to the 1990 and 1991 financial reforms may have previously encouraged entry of unproductive plants and kept existing unproductive plants afloat. Moreover, greater learning after reforms may be due to greater access to new vintages of imported capital and greater access to the know-how of foreign firms in the economy. In terms of exiting behavior, intensified foreign competition after the trade reforms seems to have increased market discipline by forcing firms either to increase productivity and charge lower prices, or else exit the market.

\section{Conclusion}

In this paper, we examine how reallocation contributes to productivity and other determinants of profitability in Colombia. Then, we ask how the relation between reallocation and productivity and demand factors changed after market reforms were introduced in Colombia during the early 1990's. The extent, breadth and swiftness of the reforms make Colombia a superb country to study these issues. In addition, a unique feature of the Colombian data is that it allows us to measure both plant-level quantities and prices, making these data ideal for measuring plant-level productivity and demand.

We propose a sequential methodology for estimating both productivity and demand shocks at the plant level. First, we generate measures of plant-level total factor productivity by estimating KLEM production functions using plantlevel physical output data. To eliminate biases from the correlation between 
productivity shocks and inputs, we use downstream demand shifts and plantlevel energy and materials prices as instruments in estimating production functions. We then generate plant-level demand shocks by estimating inversedemand equations using plant-level output prices, where output is instrumented with TFP to eliminate biases from the correlation between demand shocks and output.

We find some interesting patterns with regards to total factor productivity, prices and demand shocks in Colombia, which sometimes contrast with the patterns found for the U.S. First, as in the U.S., we find a great deal of heterogeneity in terms of productivity and output prices, and we find that this heterogeneity has been increasing over the past decades. Second, we find a large degree of persistence in productivity, prices and demand, which doubles or triples the degree of persistence found in the U.S.

We also explore turnover dynamics in Colombia during the entire period of study as well as before and after the introduction of reforms. First, consistent with recent evidence for the U.S. which uses plant-level prices, we find that entering business are more productive than incumbents and the exiting businesses they are replacing, and that exiting businesses are much less productive than incumbents. Note that revenue-based TFP measures spuriously include a demand component and thus underestimate the technical efficiency of entrants, who have to build a consumer base, relative to incumbents, who have a established clientele. For this reason, our analysis provides a better basis to discern between vintage and learning models. Our results are more consistent with a vintage capital explanation than a learning explanation of industry dynamics. In addition, we find that turnover is affected by demand-side factors, as both entering and exiting plants face lower demand for their products than incumbents. Second, we explore how these patterns changed in response to market reforms. After the reforms, entering businesses no longer had as much initial productivity advantage relative to incumbents, but the productivity of exiting plants relative to incumbents falls substantially. On net, the contribution of entry and exit rises slightly. This is consistent with increased redundancy of unproductive workers, who were previously retained by plants due to high dismissal costs, and with increased exit of plants which may had been kept afloat by subsidized credit, relatively low taxes, and limited foreign competition before 1990. When we explore a more dynamic specification, we find evidence of learning effects for surviving entrants after the reforms. This is consistent with a contribution to learning due to trade and foreign direct investment liberalization. The increased competition also imposed market discipline, forcing plants to either increase productivity and charge lower prices, or exit the market. On the other hand, access to new vintages of imported capital also contributes to productivity growth if lower capital adjustment costs increase the optimal frequency of retooling to install equipment embedding latest technology.

Not surprisingly, we find that the allocation of activity across businesses reflects both efficiency and demand factors. Businesses with higher TFP and higher demand have a higher market share. The more interesting question is how these patterns changed in response to market reforms. We find that, after 
the reforms, there is a significant increase in the importance of efficiency and a decline in the importance of demand factors in determining productivity. This change in the efficiency of allocation has a large impact on aggregate productivity. Specifically, we find that the higher aggregate productivity in Colombia over this period (for the average 3-digit industry) is largely accounted for by the improved allocation of activity to high-productivity businesses. We also find that demand factors become less important after market reforms in determining the allocation of activity which is consistent with the implications of increased product market competition.

Our paper takes a first look at the impact of the reforms on the relation between efficiency and demand-side factors and the allocation of activity by essentially asking whether the covariance structure of productivity, demand shocks and the allocation of activity changes after the reforms. While instructive, much research remains to be done in this context, in particular to investigate the reforms with more information and structure. In future work, we plan to explore the temporal and cross-sectional variation of the various reforms more fully. Not all the market reforms happened at the exact same time, and many of the market reforms likely impacted firms differentially depending upon sector and other characteristics (e.g., factor intensities, size, and location) of the businesses. Moreover, we plan to explore the dynamic implications of the reforms in terms of their impact on market selection in Colombia.

\section{References}

[1] Aghion, Philippe and Peter Howitt. 1992. "A Model of Growth Through Creative Destruction," Econometrica, 60(2): 323-351.

[2] Aw, Bee-Yan, Siaomin Chen, and Mark Roberts. 1997. "Firm-level Evidence on Productivity Differentials, Turnover and Exports in Taiwanese Manufacturing, NBER Working Paper 6235.

[3] Bartelsman, Eric, Martin Baily and John Haltiwanger. 2001. "Labor Productivity: Structural Change and cyclical Dynamics," Review of Economics and Statistics, 83(3): 420-433.

[4] Bartelsman, Eric and Mark Doms. 2000. "Understanding Productivity: Lessons from Longitudinal Microdata," Journal of Economic Literature, 38(2): 569-594.

[5] Bartelsman, Eric and Phebus Dhrymes. 1998. "Productivity Dynamics: U.S. Manufacturing Plants 1972-1986," Journal of Productivity Analysis, $9(1): 5-34$.

[6] Bartelsman, Eric, Ricardo Caballero and Richard Lyons. 1994. "Customerand Supplier-Driven Externalities," American Economic Review, 84(4): 1075-1084. 
[7] Baily, Martin, Charles Hulten and David Campbell. 1992. "Productivity Dynamics in Manufacturing Establishments," Brookings Papers on Economic Activity: Microeconomics, 187-249.

[8] Basmann, Robert. 1960. "On Finite Sample Distributions of Generalized Classical Linear Identifiability Test Statistics," Journal of the American Statistical Association, 55: 650-659.

[9] Bernard, Andrew, Jonathan Eaton, Bradford Jensen and Samuel Kortum. 2003. "Plants and Productivity in International Trade," American Economic Review, 93(4): 1268-1291.

[10] Bernard, Andrew and Bradford Jensen. 1999. "Exceptional Exporter Performance: Cause, Effect, or Both?," Journal of International Economics, 47(1): 1-38.

[11] Bigsten, Arne, Paul Collier, Stefan Dercon, Bernard Gauthier, Jan Gunning Anders Isaksson, Abena Oduro, Remco Oostendrop, Cathy Pattillo, Mans Soderbom, Michel Sylvain, Francis Teal and Albert Seufack. 1997. "Exports and Firm-level Efficiency in the African Manufacturing Sector," University of Montreal.

[12] Basu, Susanto and John Fernald. 1997. "Returns to Scale in U.S. Production: Estimates and Implications," Journal of Political Economy, 105(2): 249-283.

[13] Burki, Shajid and Guillermo Perry. 1997. The Long March: A Reform Agenda for Latin America and the Caribbean for the Next Decade. Washington D.C.: World Bank.

[14] Caballero, Ricardo, and Mohamad Hammour. 1994. "The Cleansing Effects of Recessions," American Economic Review, 84(5): 1356-68.

[15] Caballero, Ricardo, and Mohamad Hammour. 1996. "On the Timing and Efficiency of Creative Destruction," Quarterly Journal of Economics, 111(3): 805-852.

[16] Chen, Tain-jy and De-piao Tang. 1987. "Comparing Technical Efficiency Between Import-Substitution-Oriented and Export-Oriented Foreign Firms in a Developing Country," Journal of Development Economics, 36: 277-289.

[17] Clerides, Sofronis, Saul Lach and James Tybout. 1998. "Is Learning by Exporting Important? Micro-dynamic Evidence from Colombia, Mexico and Morocco," Quarterly Journal of Economics, 113(3): 903-947.

[18] Davis, Steven, John Haltiwanger and Scott Schuh. 1996. Job Creation and Destruction. Cambridge, Mass.: MIT Press.

[19] Edwards, Sebastian. 2001. The Economic and Political Transition to an Open Market Economy: Colombia. Paris: OECD. 
[20] Ericson, Richard and Ariel Pakes.1995. "Markov-Perfect Industry Dynamics: A Framework for Empirical Work," Review of Economic Studies, 62(1): 53-82.

[21] Foster, Lucia, John Haltiwanger, and Chad Syverson. 2003. "Reallocation, Firm Turnover, and Efficiency: Selection on Productivity or Profitability?," University of Maryland, Mimeo.

[22] Foster, Lucia, John Haltiwanger, and Cornell Krizan. 2001. "Aggregate Productivity Growth: Lessons from Microeconomic Evidence," in Edward Dean Michael Harper and Charles Hulten, eds., New Developments in Productivity Analysis. Chicago: University of Chicago Press.

[23] Hall, Robert. 1990. "Invariance Properties of Solow's Productivity Residual," in Peter Diamond, ed., Growth/Productivity/Unemployment. Cambridge: MIT Press.

[24] Haltiwanger, John. 2000. "Aggregate Growth: What Have We Learned from Microeconomic Evidence?," University of Maryland, Mimeo.

[25] Harrison, Ann. 1994. "Productivity, Imperfect Competition, and Trade Reform: Theory and Evidence," Journal of International Economics, 36: 5373 .

[26] Hopenhayn, Hugo. 1992. "Entry, Exit, and Firm Dynamics in Long Run Equilibrium," Econometrica, 60(5): 1127-50.

[27] Jovanovic, Boyan. 1982. "Selection and the Evolution of Industry," Econometrica, 50(3): 649-670.

[28] Kugler, Adriana and Maurice Kugler. 2003. "The Labor Market Effects of Payroll Taxes in a Middle-Income Country: Evidence from Colombia," CEPR Working Paper No. 4046.

[29] Kugler, Adriana. 2004. "Wage-Shifting Effects of Severance Payments Savings Accounts in Colombia," forthcoming in Journal of Public Economics.

[30] Kugler, Adriana. 1999. "The Impact of Firing Costs on Turnover and Unemployment: Evidence from the Colombian Labor Market Reform," International Tax and Public Finance Journal, 6(3): 389-410.

[31] Kugler, Maurice. 2000. "The Diffusion of Externalities from Foreign Direct Investment: The Sectoral Pattern of Spillovers," Essays on International Technology Diffusion, Chapter 1, Ph.D. Dissertation, UC Berkeley.

[32] Kugler, Maurice and Howard Rosenthal. 2004. "Checks and Balances: An Assessment of the Institutional Separation of Powers in Colombia," in Alberto Alesina, ed., Institutional Reforms in Colombia, MIT Press. 
[33] Levinshohn, James and Amil Petrin. 1997. "Productivity, Industry Dynamics, and International Competition: A Structural Econometric Approach," University of Michigan, Mimeo.

[34] Liu, Lili. 1996. "Entry-Exit, Learning and Productivity Change: Evidence from Chile," Journal of Development Economics, 42: 217-42.

[35] Lora, Eduardo. 2000. "What Makes Reforms Likely? Timing and Sequencing of Structural Reforms in Latin America," Inter-American Development Bank Working Paper No. 424.

[36] Lora, Eduardo. 1997. "A Decade of Structural Reforms in Latin America: What Has Been Reformed and How to Measure It," Inter-American Development Bank Working Paper No. 348.

[37] Marschak, Jacob and William Andrews. 1944. "Random Simultaneous Equations and the Theory of Production," Econometrica, 12 (3) 143-172.

[38] Melitz, Marc. 2003. "The Impact of Trade on Intra-Industry Reallocations and Aggregate Industry Productivity," forthcoming in Econometrica.

[39] Melitz, Marc. 2003. "Estimating Firm-Level Productivity in Differentiated Product Industries," Harvard University, Mimeo.

[40] Pack, Howard. 1984. Productivity, Technology, and Industrial Development: A Case Study in Textiles. New York: Oxford University Press.

[41] Pombo, Carlos. 1999. "Productividad Industrial en Colombia: Una Aplicacion de Numeros Indices," Revista de Economia del Rosario.

[42] Roberts, Mark and Emmanuel Skoufias. 1997. "The Long-run Demand for Skilled and Unskilled Labor in Colombian Manufacturing Plants," Review of Economics and Statistics, 79(2): 330-337.

[43] Roberts, Mark and James Tybout. 1997. "The Decision to Export in Colombia: An Empirical Model of Entry with Sunk Costs," American Economic Review, 87(4): 545-565.

[44] Roberts, Mark and James Tybout. Industrial Evolution in Developing Countries: Micro Patterns of Turnover, Productivity and Market Structure. New York: Oxford University Press, 1996.

[45] Roberts, Mark and Dylan Supina. 1996. "Output Price, Markups, and Producer Size," European Economic Review, 40(3-5): 909-21.

[46] Roberts, Mark and Dylan Supina. 1996. "Output Price and Markup Dispersion in Microdata: The Roles of Producer Heterogeneity and Noise," in Michael Baye, ed., Advances in Applied Microeconomics, Vol. 9. JAI Press. 
[47] Roberts, Mark and James Tybout. 1996. Industrial Evolution in Developing Countries: Micro Patterns of Turnover, Productivity and Market Structure. New York: Oxford University Press.

[48] Shea, John. 1997. "The Input-Output Approach to Instrument Selection," Journal of Business and Economic Statistics, 11(2): 145-155.

[49] Shea, John. 1993. "Do Supply Curves Slope Up?" Quarterly Journal of Economics, 108(1): 1-32.

[50] Syverson, Chad. 2003. "Market Structure and Productivity: A Concrete Example, University of Chicago, Mimeo.

[51] Syverson, Chad. 2002. "Price Dispersion: The Role of Product Substitutability and Productivity," University of Chicago, Mimeo.

[52] Tybout, James. 2000. "Manufacturing Firms in Developing Countries: How Well Do They Do, And Why?, Journal of Economic Literature, 38(1): 1134.

[53] Tybout, James and Daniel Westbrook. 1995. "Trade Liberalization and Dimensions of Efficiency Change in Mexican Manufacturing Industries," Journal of International Economics, 39(1-2): 53-78. 


\section{Appendix: Longitudinal Linkages in the AMS Data}

The identification of establishments in the AMS for the period 1982-1998 has overcome changes in sampling and labeling of plants. In essence, there are three groups of plant identifiers: a system that allows following plants from 1982 to $1991,{ }^{28}$ another system that can be used to follow plants from 1993 onwards, and finally a transition system that is supposed to provide the necessary link over the transition period (1991-1993). Nevertheless, the latter set is quite incomplete, so that many plants that existed prior to 1992 and survived until after 1993 cannot be successfully identified as continuers. As a result, matching plants using the transition identifiers leads to spurious calculations of entry and exit. To solve this problem, we relied on some existing records of additional identifiers that, although incomplete, provide some information about the different identifiers a given plant was assigned over the period. This additional effort eliminated a large fraction of the spurious entry and exit. For instance, after performing this additional matching, we are unable to follow only 740 plants after 1991, while in previous independent attempts documented by DANE the corresponding figure was 4083. However, 740 "deaths" in a year is still too high a figure compared to the historic yearly exit rates. Similarly, we obtain too high an entry rate for 1992 relative to historic levels, to be fully explained by fundamentals.

Spuriously high exit and entry rates stem from two sources. First, changes in the sample resulting from the change of survey unit from establishment to enterprise. In particular, from 1992 if a firm that owns various establishment satisfies the requirements to enter the sample, each of its establishments is included, independently of whether the plant itself satisfies the requirements or not. ${ }^{29}$ Before 1992, meanwhile, only establishments that satisfied the requirements were included in the sample, independently of their ownership. To solve the problem of sample change, we deleted from our base of each year the establishments that do not satisfy the requirements of the sample. ${ }^{30}$

\footnotetext{
${ }^{28}$ This is the time period covered by the subset of AMS data used by Roberts and Tybout (1996) and Clerides, Lach and Tybout (1998). Note that their sample does not include any years after the implementation of structural reforms in Colombia, nor does it have plant-level price indices.

${ }^{29}$ These requirements are that an establishment must have 10 or more employees or have a production superior to a given limit. Such limit was 25 million Colombian Pesos (in current terms) for 1982-1991, 50 million for 1992-1995, 60 million for 1996-1997, and 70.5 million for 1998. One obvious problem of these requirements is that the minimum production has always been established in current pesos, and has not been properly modified to reflect inflation. With an average PPI inflation of around $20 \%$, the minimum real production required for inclusion in the sample decreased dramatically over those years where the limit was kept constant. This may be affecting the levels of entry and exit; our measure of entry will actually be an upper bound of entry, while the opposite will happen with our measure of exit. Notwithstanding this problem, we decided not to change the requirements to enter the sample because the only non-arbitrary method we found (deflating the limits by some known deflator, like PPI) leads to an underestimation of the growth of the industry. Moreover, the limit on the number of employees is the binding requirement in most cases.

${ }^{30}$ One point to note is that, apparently, the change in methodology also included surveying
} 
Secondly, there are possible mistakes in the assignment of codes, that make impossible to match an establishment between 1991 and 1992, even though the establishment continues over the period. The solution to this problem implies matching what now is a "death of 1991" with what now appears to be an "entry of 1992". This matching must use additional information, such as the one contained in the directories where data on the name, tax identification number, location, and other characteristics of the plant are recorded. We therefore resorted to these directories. Due to differences in the format of the information, only the data on phone number, sector identification code and municipality were used for this match. Unfortunately, this new attempt yielded very few matches.

Given the failure of the efforts documented above to fully solve the problem of spurious entry and exit over the transition period, we implemented a probabilistic approach to eliminate the remaining problems. Our methodology involves estimating the probabilities, on the basis of observable characteristics, of entering and exiting of the plants that, after the previous procedures, appear as exiting in 1991 or entering in 1992. We used a Probit estimation procedure to model the probability of entry and the probability of exit in any given year. We defined the discrete variables ENTER and EXIT for entry and exit, respectively, with the values of 1 for event and 0 for nonevent. In our model, a plant of a given sector and a given geographic region enters (exits) when its expected profits are higher (lower) than an exogenously given limit. Profits $\pi_{j t}$ are a linear function of (real) output and number of employees. The probability of entry and exit within a sector and a geographic region is, therefore, a function of output and employment.

Let $s$ be a subscript for 2 digits sector and $r$ be a subscript for region (Atlantic, Pacific, Central, and Antioquia plus Viejo Caldas). Then, for plant $j$ that belongs to sector $s$ and region $r$, let $e_{j t}=1$ if plant $j$ enters in year $t$, with $e_{j t}=0$ otherwise, and $x_{j t}=1$ if plant $j$ exits in year $t$, with $x_{j t}=0$ otherwise.

The entry probability may be expressed as,

$$
\operatorname{Pr}\left(e_{j t}=1\right)=\operatorname{Pr}\left(\pi_{j t}>\pi^{*}\right)=\operatorname{Pr}\left(\beta_{0, s r}+\beta_{1, s r} Y_{j t}+\beta_{2, s r} L_{j t}+\epsilon_{j t}>\pi^{*}\right)
$$

Assuming $\epsilon_{j t}$ follows a cumulative normal distribution denoted by $F$,

$$
\operatorname{Pr}\left(e_{j t}=1\right)=1-F\left(-X_{j t}^{\prime} \psi\right)=F\left(X_{j t}^{\prime} \psi\right)
$$

where the last step follows from the fact that $F$ is a symmetric distribution, and $X_{j t}=\left[\mathbf{1}^{\prime}, Y_{j t}^{\prime}, L_{j t}^{\prime}\right]$ and $\psi^{\prime}=\left[\beta_{0}-\pi^{*}, \beta_{1}, \beta_{2}\right]$.

establishments that were not in the sample even though they did satisfy the requirements (due to previous failures in enforcing the requirement to report to the AMS). This modification is not formally documented, but DANE staff have reported that an effort was made in 1992 to improve the actual coverage of the survey. To the extent that this is the case, the solution proposed above to the problem of change in sample (namely, to keep only establishments that satisfy the sample criteria) will not fully alleviate the problem. 
When estimating the model for entry in 1992 (exit in 1991), we used information by sector and geographic region, where all years and plants where pooled. For each estimation we excluded the plants for which we wanted to predict the probability of event (plants that after the previous procedures appear as entering in 1992 or exiting in 1991). For the data used in the estimations, the model predicted correctly between $50 \%$ and $88 \%$ of the observed responses, depending on the sector-region combination. For most groups the model predicted correctly about $70 \%$ of the responses. With the estimated parameters we calculated the predicted probabilities of entering in 1992 (exiting in 1991) using the data for plants that in our database appeared as entries of 92 (exits of 91). Out of these groups, we kept in our database only the 179 (372) plants that presented highest predicted probabilities of entering (exiting). The number of plants we actually kept in the sample corresponds to the average of entries in 1991 and 1993 (exits in 1990 and 1992). 
Figure 1: TFP Dispersion for Continuing, Entering, and Exiting Plants,

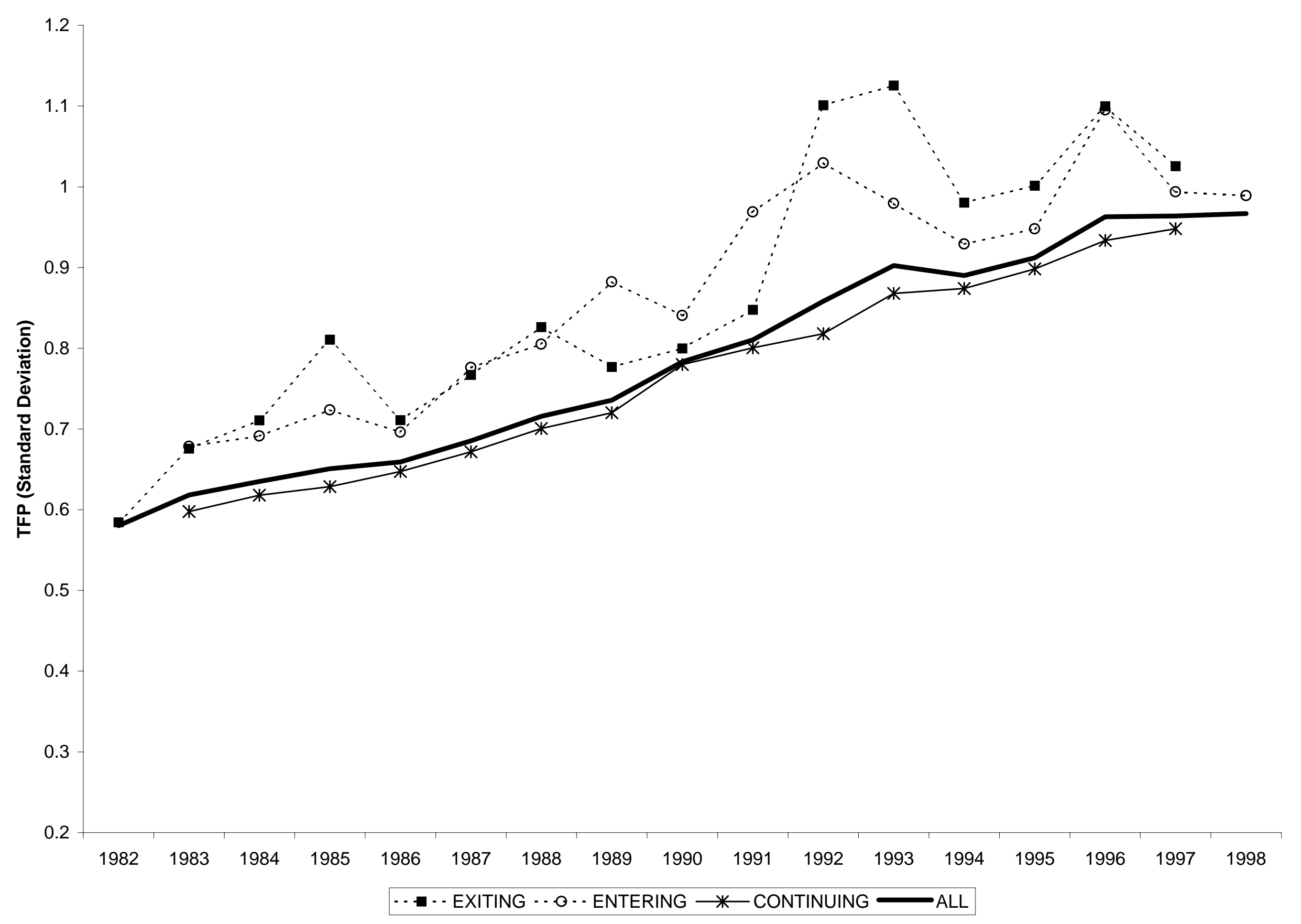


Figure 2: Dispersion of Demand Shocks for Continuing, Entering, and Exiting Plants,

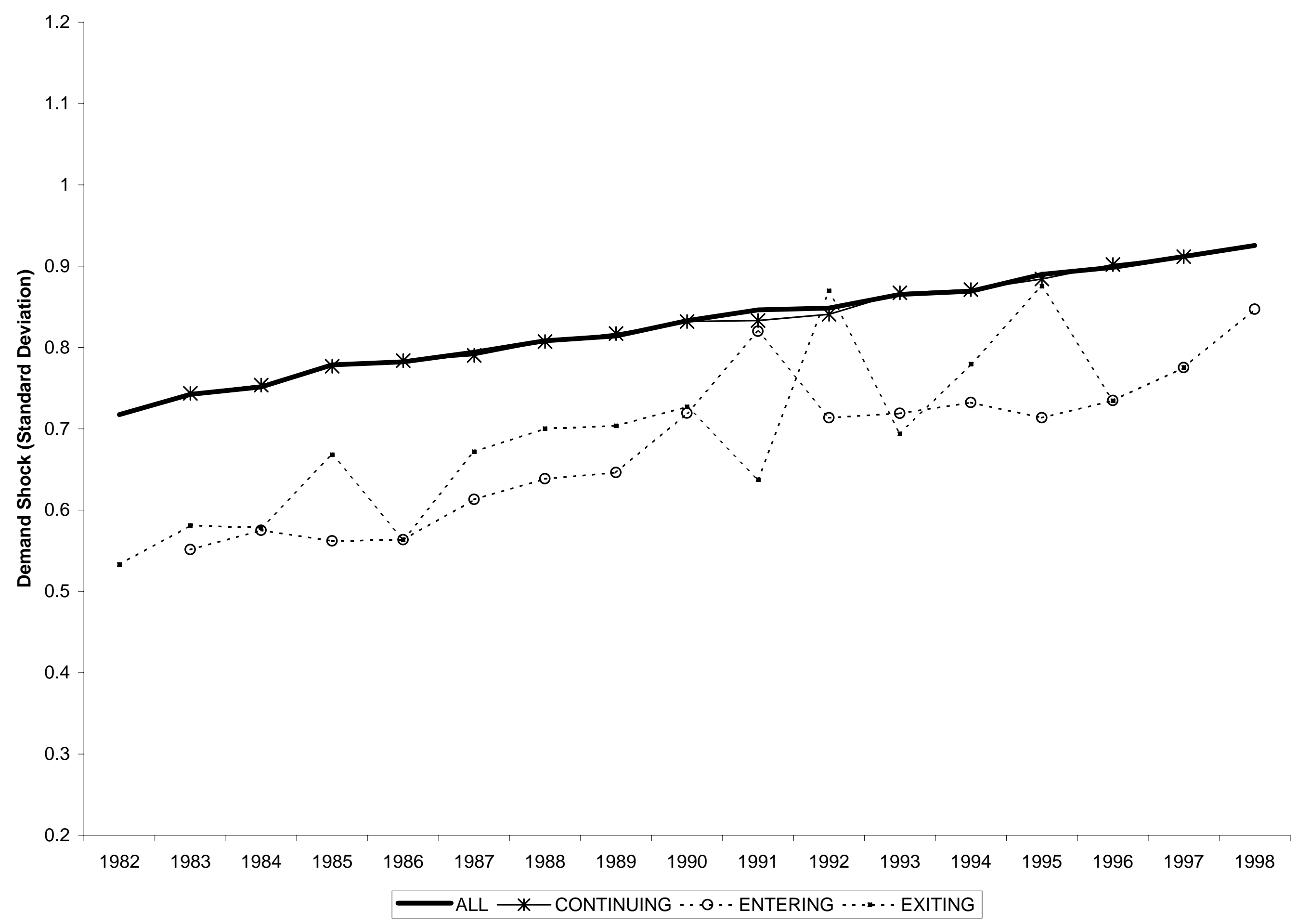


Figure 3: Output Prices Dispersion for Continuing, Entering, and Exiting Plants,

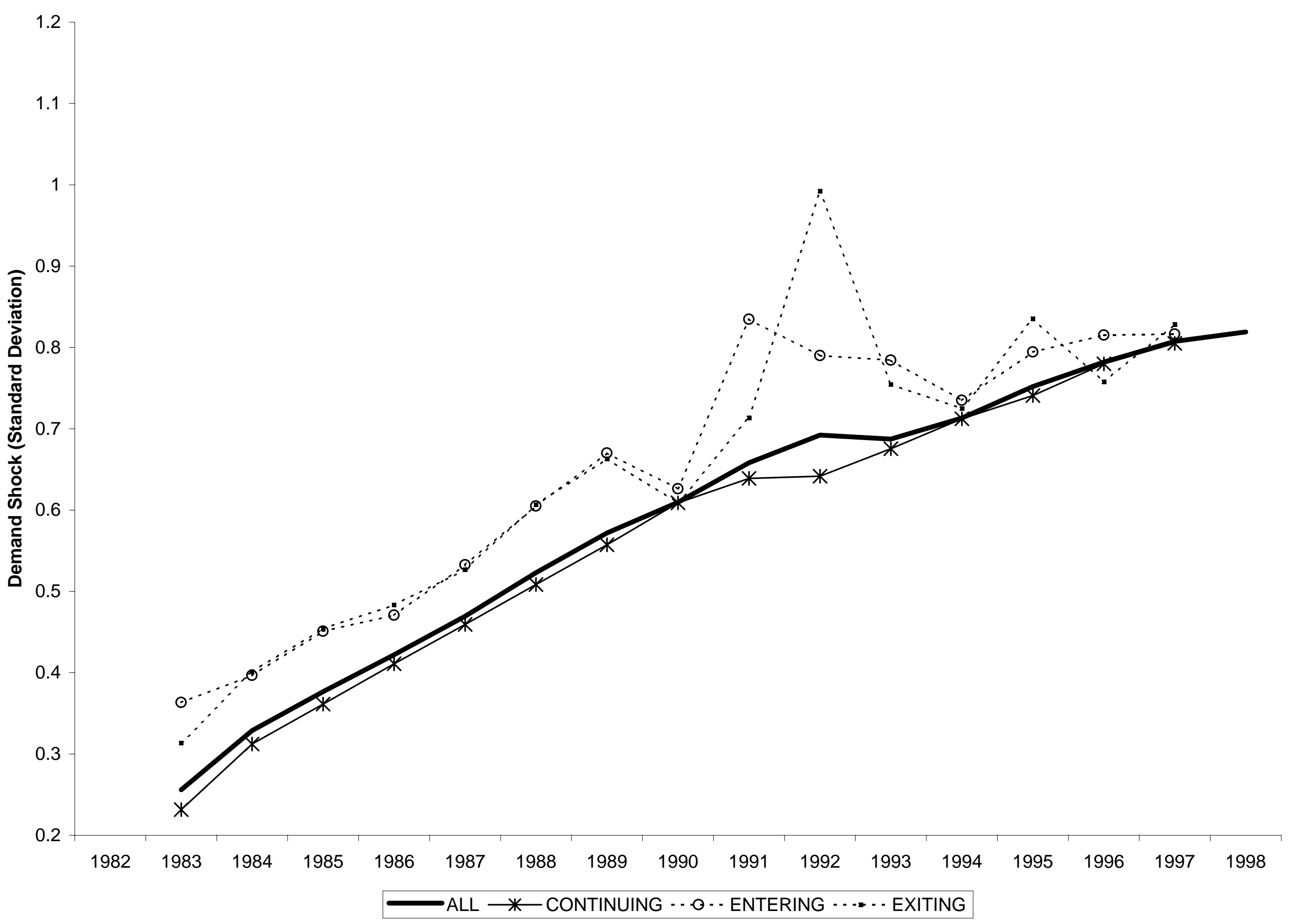


Figure 4: Kernel Distribution of TFP

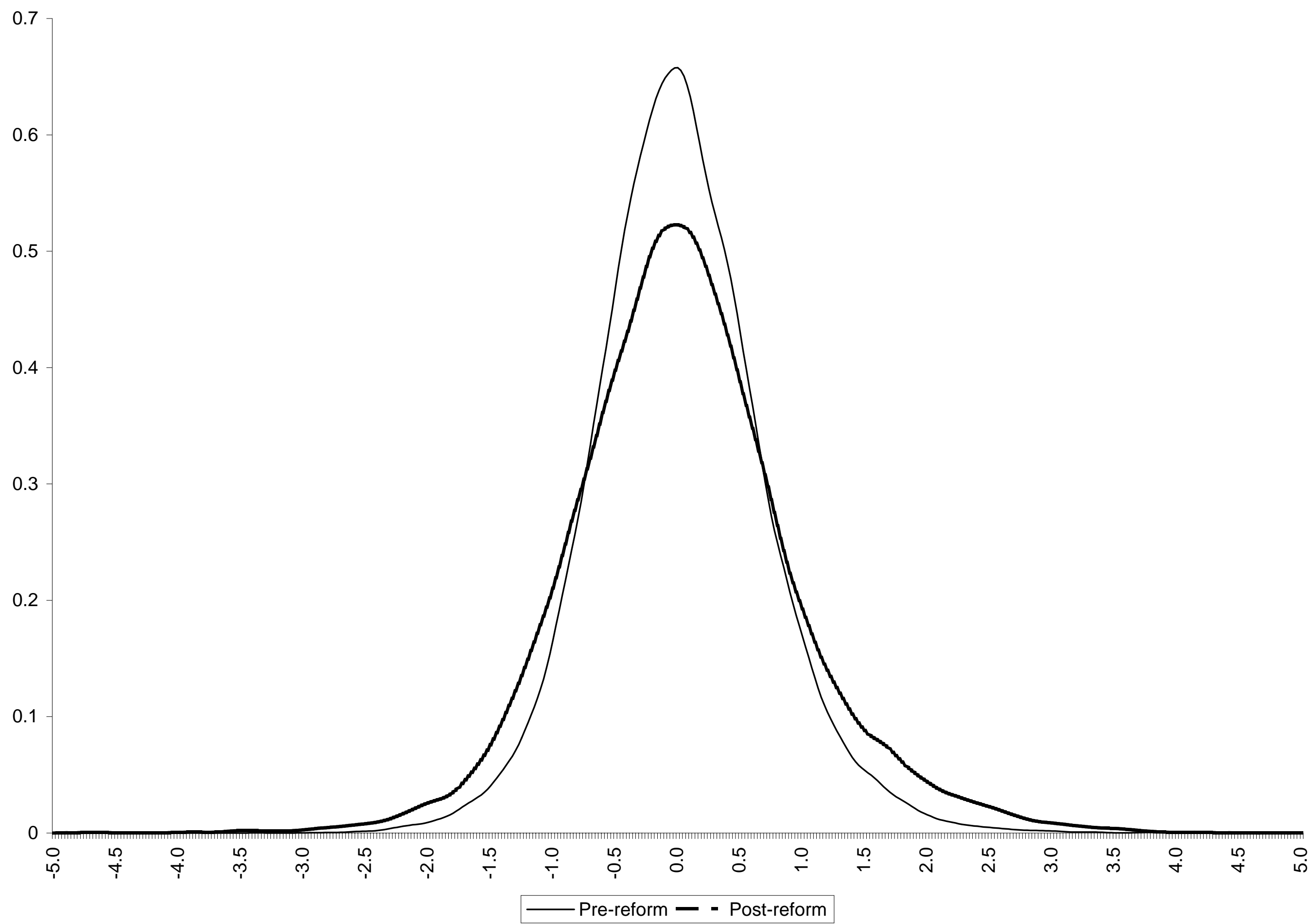


Figure 6: Kernel Distribution of Relative Prices

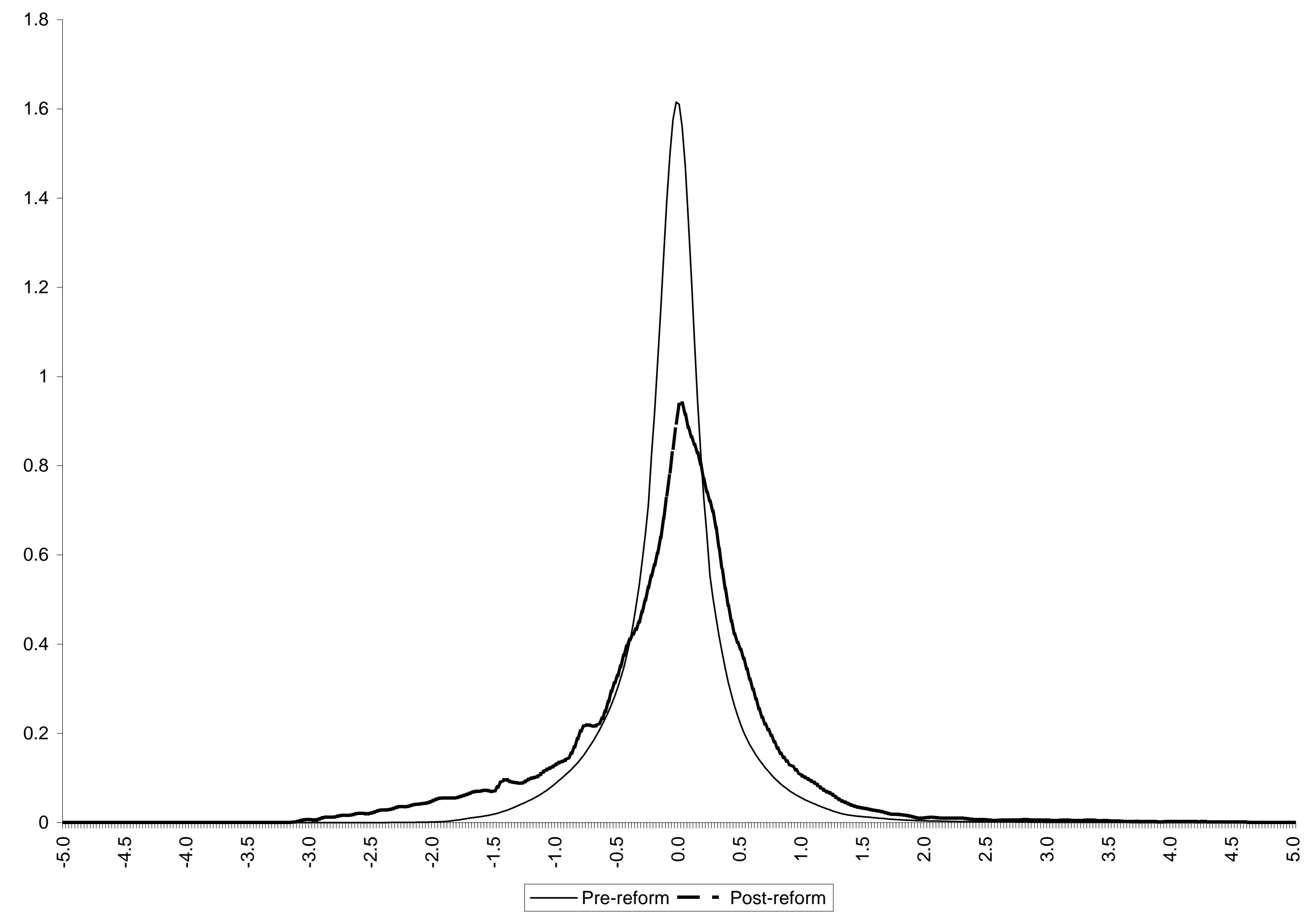


Figure 7: Cross-Sectional Decomposition of TFP, 1982-1998

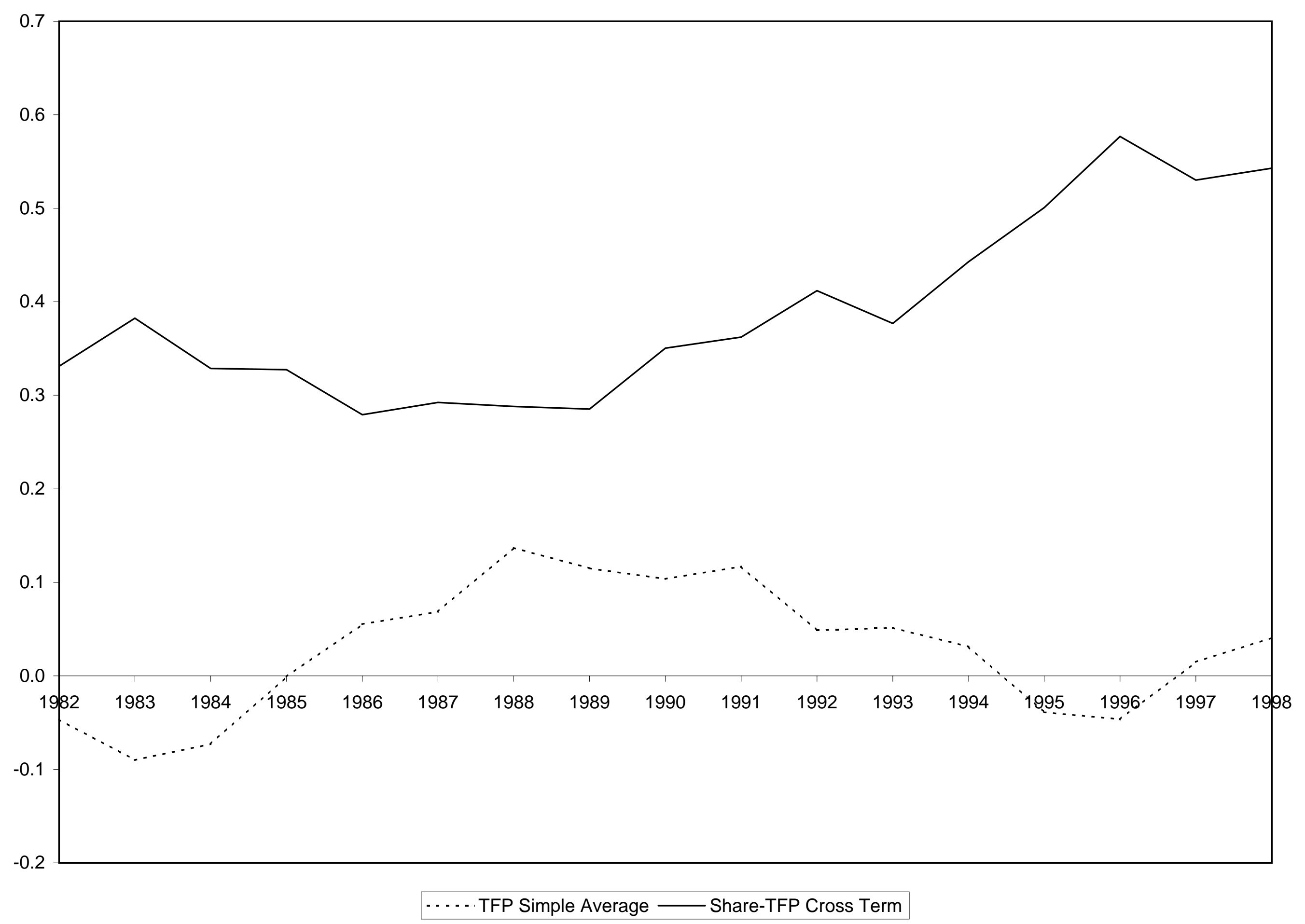


Figure 8: Cross-Sectional Decomposition of Demand Shock, 1982-1998

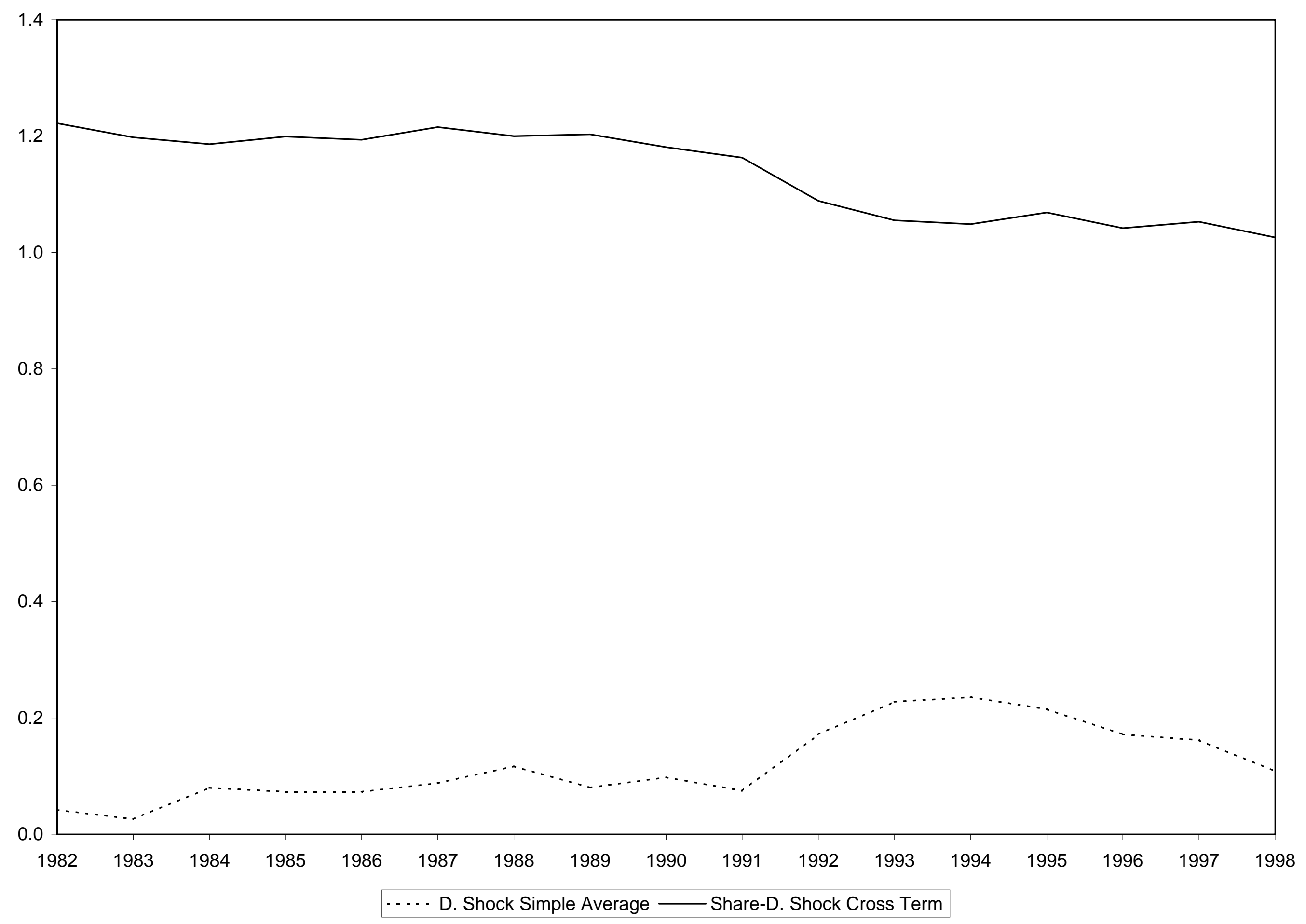


Table 1: Descriptive Statistics for Continuing, Entering, and Exiting Plants, Before and After Market-Oriented Reforms

\begin{tabular}{|c|c|c|c|c|c|c|c|c|}
\hline \multirow[b]{2}{*}{ Variable } & \multicolumn{4}{|c|}{ Pre-Reforms } & \multicolumn{4}{|c|}{ Post-Reforms } \\
\hline & All & Continuers & Entrants & Exits & All & Continuers & Entrants & Exits \\
\hline \multirow[t]{2}{*}{ Output } & 10.49 & 10.72 & 9.47 & 9.39 & 10.90 & 11.12 & 9.87 & 9.72 \\
\hline & (1.67) & $(1.66)$ & $(1.29)$ & $(1.36)$ & (1.88) & (1.83) & (1.64) & (1.60) \\
\hline \multirow[t]{2}{*}{ Capital } & 8.21 & 8.42 & 6.93 & 7.30 & 8.75 & 8.91 & 7.51 & 7.76 \\
\hline & $(2.05)$ & $(2.04)$ & (1.66) & (1.81) & $(2.18)$ & $(2.15)$ & $(1.91)$ & (1.96) \\
\hline \multirow[t]{2}{*}{ Labor } & 10.97 & 11.08 & 10.21 & 10.32 & 10.95 & 11.13 & 10.15 & 10.30 \\
\hline & $(1.1)$ & (1.10) & $(0.78)$ & $(0.83)$ & $(1.25)$ & (1.23) & (1.07) & (1.11) \\
\hline \multirow[t]{2}{*}{ Energy } & 11.30 & 11.51 & 10.16 & 10.34 & 11.55 & 11.76 & 10.45 & 10.64 \\
\hline & $(1.88)$ & (1.89) & $(1.42)$ & (1.55) & (1.99) & (1.97) & $(1.71)$ & $(1.75)$ \\
\hline \multirow[t]{2}{*}{ Materials } & 9.61 & 9.83 & 8.58 & 8.48 & 10.25 & 10.45 & 9.32 & 8.99 \\
\hline & $(1.85)$ & (1.83) & (1.54) & $(1.57)$ & (1.88) & (1.84) & (1.66) & (1.71) \\
\hline Output & -0.08 & -0.09 & -0.07 & -0.06 & -0.15 & -0.15 & -0.10 & -0.09 \\
\hline Prices & $(0.44)$ & $(0.46)$ & $(0.51)$ & $(0.47)$ & $(0.74)$ & $(0.71)$ & $(0.8)$ & $(0.81)$ \\
\hline Energy & 0.25 & 0.28 & 0.32 & 0.22 & 0.55 & 0.55 & 0.61 & 0.55 \\
\hline Prices & $(0.50)$ & $(0.52)$ & $(0.55)$ & $(0.49)$ & $(0.43)$ & $(0.41)$ & $(0.49)$ & $(0.41)$ \\
\hline Material & 0.02 & 0.02 & 0.05 & 0.02 & -0.10 & -0.09 & -0.13 & -0.01 \\
\hline Prices & $(0.35)$ & $(0.37)$ & $(0.43)$ & $(0.38)$ & $(0.57)$ & $(0.53)$ & $(0.71)$ & $(0.73)$ \\
\hline Entry Rate & 0.0981 & & & & 0.0843 & & & \\
\hline Exit Rate & 0.0873 & & & & 0.1069 & & & \\
\hline $\mathrm{N}$ & 55,298 & 41,265 & 4,846 & 4,826 & 44,816 & 32,395 & 3,778 & 4,202 \\
\hline
\end{tabular}

Notes: This table reports means and standard deviations of the log of quantities and of prices deviated from yearly producer price indices. The entry and exit rates are the number of entrants divided by total plants and number of exiting firms divided by total number of plants. The pre-reform period includes the years 1982-90 and the post-reform period includes the years 1991-98. 
Table 2: Correlations of Variables

\begin{tabular}{|c|c|c|c|c|c|c|c|c|}
\hline & Output & Capital & Labor & Energy & Materials & $\begin{array}{l}\text { Output } \\
\text { Prices }\end{array}$ & $\begin{array}{c}\text { Energy } \\
\text { Price }\end{array}$ & $\begin{array}{l}\text { Materials } \\
\text { Prices }\end{array}$ \\
\hline Output & $\begin{array}{c}1.0 \\
{[100,114]}\end{array}$ & $\begin{array}{c}0.7550 \\
{[96,232]}\end{array}$ & $\begin{array}{c}0.7393 \\
{[99,102]}\end{array}$ & $\begin{array}{c}0.7649 \\
{[99,476]}\end{array}$ & $\begin{array}{c}0.8982 \\
{[90,938]}\end{array}$ & $\begin{array}{c}-0.2918 \\
{[100,114]}\end{array}$ & $\begin{array}{c}-0.0591 \\
{[100,095]}\end{array}$ & $\begin{array}{c}-0.0705 \\
{[91,540]}\end{array}$ \\
\hline Capital & & $\begin{array}{c}1.0 \\
{[96,232]}\end{array}$ & $\begin{array}{c}0.6904 \\
{[95,303]}\end{array}$ & $\begin{array}{c}0.7592 \\
{[95,684]}\end{array}$ & $\begin{array}{c}0.7267 \\
{[87,519]}\end{array}$ & $\begin{array}{c}-0.0092 \\
{[96,232]}\end{array}$ & $\begin{array}{c}-0.0082 \\
{[96,213]}\end{array}$ & $\begin{array}{c}-0.0241 \\
{[88,066]}\end{array}$ \\
\hline Labor & & & $\begin{array}{c}1.0 \\
{[99,102]}\end{array}$ & $\begin{array}{c}0.6963 \\
{[98,484]}\end{array}$ & $\begin{array}{c}0.6761 \\
{[90,073]}\end{array}$ & $\begin{array}{c}0.0084 \\
{[99,102]}\end{array}$ & $\begin{array}{c}-0.0389 \\
{[99,083]}\end{array}$ & $\begin{array}{c}0.0067 \\
{[90,671]}\end{array}$ \\
\hline Energy & & & & $\begin{array}{c}1.0 \\
{[99,476]}\end{array}$ & $\begin{array}{c}0.7492 \\
{[90,394]}\end{array}$ & $\begin{array}{c}0.0087 \\
{[99,476]}\end{array}$ & $\begin{array}{c}-0.1198 \\
{[99,457]}\end{array}$ & $\begin{array}{c}-0.0188 \\
{[90,944]}\end{array}$ \\
\hline Materials & & & & & $\begin{array}{c}1.0 \\
{[90,938]}\end{array}$ & $\begin{array}{c}-0.0063 \\
{[90,938]}\end{array}$ & $\begin{array}{c}0.0207 \\
{[90,929]}\end{array}$ & $\begin{array}{c}-0.2384 \\
{[90,938]}\end{array}$ \\
\hline $\begin{array}{l}\text { Output } \\
\text { Prices }\end{array}$ & & & & & & $\begin{array}{c}1.0 \\
{[100.114]}\end{array}$ & $\begin{array}{c}-0.0047 \\
{[100.095]}\end{array}$ & $\begin{array}{c}0.2469 \\
{[91.540]}\end{array}$ \\
\hline Energy & & & & & & & 1.0 & -0.0118 \\
\hline Prices & & & & & & & {$[100,095]$} & {$[91,531]$} \\
\hline Materials & & & & & & & & 1.0 \\
\hline Prices & & & & & & & & {$[91,540]$} \\
\hline
\end{tabular}

Notes: The table includes bivariate correlations of logs of quantities and price deviations from yearly producer price indices. The numbers in square brackets are the number of observations. 
Table 3: Production Function Equations

\begin{tabular}{|c|c|c|c|c|}
\hline & \multicolumn{2}{|c|}{ OLS } & \multicolumn{2}{|c|}{$2 \mathrm{SLS}$} \\
\hline & (1) & (2) & (3) & (4) \\
\hline Capital & $\begin{array}{l}0.3226 \\
(0.004)\end{array}$ & $\begin{array}{c}0.0764 \\
(0.0025)\end{array}$ & $\begin{array}{c}0.4646 \\
(0.0165)\end{array}$ & $\begin{array}{c}0.3027 \\
(0.0225)\end{array}$ \\
\hline Labor & $\begin{array}{c}0.7411 \\
(0.0071)\end{array}$ & & $\begin{array}{c}1.0398 \\
(0.0596)\end{array}$ & \\
\hline Labor Hours & & $\begin{array}{c}0.2393 \\
(0.0037)\end{array}$ & & $\begin{array}{c}0.2125 \\
(0.0313)\end{array}$ \\
\hline Energy & & $\begin{array}{c}0.124 \\
(0.0028)\end{array}$ & & $\begin{array}{c}0.1757 \\
(0.0143)\end{array}$ \\
\hline Materials & & $\begin{array}{c}0.5891 \\
(0.0026)\end{array}$ & & $\begin{array}{c}0.2752 \\
(0.0095)\end{array}$ \\
\hline $\mathrm{R}^{2}$ & 0.5806 & 0.8621 & 0.4787 & 0.8107 \\
\hline $\mathrm{N}$ & 42,235 & 48,114 & 42,235 & 48,114 \\
\hline
\end{tabular}

Notes: The standard errors are reported in parentheses. The regressions in Columns (1) and (3) use the $\log$ of value added as the dependent variable, where value added is revenue minus materials and energy costs, and capital and employment as the regressors. The regressions in Columns (2) and (4) use the log of physical output as the dependent variable, and capital, employment hours, energy, and materials as regressors. All regressors are in logs. The two-stage least squares regressions use the following variables to instrument the inputs: Shea's (1993) downstream demand instruments constructed as the demand for the intermediate output (calculated using the input-output matrix); one- and two-period lags of downstream demand; regional government expenditures, excluding government investment; and energy and material plant-level prices, deviated from the yearly PPI. 
Table 4: First-Stage Regressions of Inputs for Production Function Equations

\begin{tabular}{lcccc}
\hline \hline Instrumental Variables & $\begin{array}{c}\text { Capital } \\
(1)\end{array}$ & $\begin{array}{c}\text { Labor } \\
(2)\end{array}$ & $\begin{array}{c}\text { Energy } \\
(3)\end{array}$ & $\begin{array}{c}\text { Materials } \\
(4)\end{array}$ \\
\hline Downstream Demand-shift & 0.0157 & -0.1059 & 0.2005 & 0.2506 \\
& $(0.0362)$ & $(0.0207)$ & $(0.032)$ & $(0.0317)$ \\
One-period Lag of & -0.1368 & -0.0483 & -0.1456 & -0.1619 \\
Downstream Demand-shift & $(0.0499)$ & $(0.0286)$ & $(0.0441)$ & $(0.0437)$ \\
Two-period lag of & 0.3752 & 0.0558 & 0.3142 & 0.3005 \\
Downstream Demand-shift & $(0.0318)$ & $(0.0182)$ & $(0.0281)$ & $(0.0278)$ \\
Regional Current Governmer & 0.0484 & 0.085 & -0.0633 & -0.0166 \\
Expenditure & $(0.0069)$ & $(0.004)$ & $(0.0061)$ & $(0.0061)$ \\
Plant-level Energy Price & -0.2415 & -0.1257 & -0.5676 & -0.166 \\
& $(0.0199)$ & $(0.0114)$ & $(0.0176)$ & $(0.0175)$ \\
Plant-level Materials & -0.0253 & 0.0386 & 0.0166 & -0.8157 \\
Price & $(0.0188)$ & $(0.0108)$ & $(0.0166)$ & $(0.0164)$ \\
$\mathrm{R}^{2}$ & 0.0319 & 0.0127 & 0.064 & 0.1129 \\
Physical Output Partial R ${ }^{2}$ & 0.1276 & 0.139 & 0.231 & 0.324 \\
Value-added Partial R ${ }^{2}$ & 0.2563 & 0.1324 & - & - \\
N & 48,114 & 48,114 & 48,114 & 48,114 \\
\hline \hline
\end{tabular}

Notes: Standard errors are in parentheses. The variables are in logs. The price variables are deviations from the yearly PPI. Following Shea (1993), downstream demand-shift instruments are total output measures in downstream industries that meet the following two conditions: (1) their demand share for upstream production has to exceed 15\%, and (2) the share of the upstream industry in their total costs does not exceed $15 \%$. The $\mathrm{R}^{2}$ simply reports the square of the sample correlation coefficient between $I_{j t}$ and $\hat{I}_{j t}$, where $I=K, L, E, M$ and $\hat{I}_{j t}$ are the predicted values of the inputs from a regression of $I_{j t}$ on the instruments. The partial $R^{2}$ reports the sample correlation coefficient between $s_{j t}$ and $\hat{s}_{j t}$, where $s_{j t}$ are the residuals from a regression of $I_{j t}$ on all other inputs $I_{1 j \mathrm{t}}$ and $\hat{\mathrm{s}}_{\mathrm{jt}}$ are the correlations between $\hat{\mathrm{I}}_{\mathrm{jt}}$ and the predicted values of all other inputs $\hat{\mathrm{I}}_{\mathrm{jj} \mathrm{j}}$. 
Table 5: Inverse Demand Equations

\begin{tabular}{|c|c|c|c|c|c|c|c|c|c|}
\hline \multirow[b]{2}{*}{ Regressor } & \multicolumn{3}{|c|}{ OLS } & \multicolumn{3}{|c|}{ 2SLS } & \multicolumn{3}{|c|}{ First Stages } \\
\hline & (1) & $(2)$ & (3) & (4) & $(5)$ & $(6)$ & $\mathrm{R}^{2}$ & $\begin{array}{c}\text { Partial } R^{2} \\
\text { Regression } \\
(5)\end{array}$ & $\begin{array}{c}\text { Partial } \mathrm{R}^{2} \\
\text { Regression } \\
(6)\end{array}$ \\
\hline Physical & -0.0905 & -0.0858 & -0.0447 & -0.4381 & -0.4456 & -0.3158 & 0.2177 & 0.4696 & 0.427 \\
\hline Output & $(0.0011)$ & $(0.0011)$ & $(0.0015)$ & $(0.0034)$ & $(0.0035)$ & $(0.0051)$ & & & \\
\hline Post-reforms & & & $\begin{array}{c}0.9433 \\
(0.0232)\end{array}$ & & & $\begin{array}{c}2.4203 \\
(0.0730)\end{array}$ & - & - & - \\
\hline $\begin{array}{l}\text { Physical Output } \times \\
\text { Post-reforms }\end{array}$ & & $\begin{array}{l}-0.0056 \\
(0.0003)\end{array}$ & $\begin{array}{l}-0.0909 \\
(0.0021)\end{array}$ & & $\begin{array}{c}0.0104 \\
(0.0005)\end{array}$ & $\begin{array}{l}-0.2152 \\
(0.0067)\end{array}$ & 0.9585 & 0.9599 & 0.4621 \\
\hline $\mathrm{R}^{2}$ & 0.0766 & 0.0793 & 0.0966 & -1.0540 & -1.0643 & -0.9578 & - & - & - \\
\hline $\mathrm{N}$ & 86,251 & 86,251 & 86,251 & 86,251 & 86,251 & 86,251 & 86,251 & 86,251 & 86,251 \\
\hline
\end{tabular}

Notes: Standard Errors are in parentheses. The dependent variable is the plant-level price minus the yearly PPI (all in logs). Two-stage least squares regressions instrument physical output and the interaction of physical output with the TFP measure estimated using Column (4) of Table 3 and with the post-reform dummy and the TFP measure interacted with the post-reform dummy. The post-reform dummy takes the value of 1 for the period 1991-98 and 0 otherwise. The $\mathrm{R}^{2}$ simply reports the square of the sample correlation coefficient between $Y_{j t}$ and $\hat{Y}_{j t}$, where $\hat{Y}_{j t}$ is the predicted value of output from a regression of $Y_{j t}$ on the instruments. The partial $R^{2}$ reports the sample correlation coefficient between $u_{j t}$ and $\hat{u}_{j t}$, where $u_{j t}$ are the residuals from a regression of $Y_{j t}$ and $Y_{j t} \times$ Post $_{t}$ and $\hat{u}_{j t}$ are the correlations between $\hat{Y}_{j t}$ and with the predicted value $\hat{Y}_{\mathrm{jt}} \times$ Post $_{\mathrm{t}}$, when only shift changes are considered, and with the interaction between the predicted value of output, $\hat{\mathrm{Y}}_{\mathrm{j} \mathrm{t}}$, and the predicted value of the post-reform dummy. 


\section{Table 6: Descriptive Statistics of TFP, Demand Shocks and Prices, Before and After the Reforms}

\begin{tabular}{|c|c|c|}
\hline & Pre-reforms & Post-reforms \\
\hline $\begin{array}{l}\text { Total Factor } \\
\text { (TFP) }\end{array}$ & $\begin{array}{c}0.0125 \\
(0.6817) \\
\rho_{\mathrm{TFP}, \mathrm{D}}=0.1114 \\
\rho_{\mathrm{TFP}, \mathrm{P}}=-0.5205 \\
\rho_{\mathrm{TFP}, \text { output }}=0.427 \\
\rho_{\mathrm{TFP}, \text { share }}=0.1297\end{array}$ & $\begin{array}{c}0.046 \\
(0.909) \\
\rho_{\mathrm{TFP}, \mathrm{D}}=-0.0995 \\
\rho_{\mathrm{TFP}, \mathrm{P}}=-0.6934 \\
\rho_{\mathrm{TFP}, \text { output }}=0.506 \\
\rho_{\mathrm{TFP}, \text { share }}=0.1836\end{array}$ \\
\hline Demand Shock (D) & $\begin{array}{c}-0.0723 \\
(0.7826) \\
\rho_{\mathrm{D}, \mathrm{P}}=0.391 \\
\rho_{\mathrm{D}, \mathrm{output}}=0.8337 \\
\rho_{\mathrm{D}, \text { share }}=0.3778\end{array}$ & $\begin{array}{c}0.0324 \\
(0.8836) \\
\rho_{\mathrm{D}, \mathrm{P}}=0.4995 \\
\rho_{\mathrm{D}, \text { output }}=0.6243 \\
\rho_{\mathrm{D}, \text { share }}=0.2863\end{array}$ \\
\hline Output Price $(\mathrm{P})$ & $\begin{array}{c}-0.0764 \\
(0.4395) \\
\rho_{\mathrm{P}, \text { output }}=-0.1822\end{array}$ & $\begin{array}{c}-0.1509 \\
(0.7414) \\
\rho_{P, \text { output }}=-0.365\end{array}$ \\
\hline
\end{tabular}

Notes: The table reports means, standard deviations in parentheses, and bivariate correlations. The physical output measure of TFP is estimated as the residual of the production function in Column (4) of Table 3. The demand shock is estimated as the residual of the inverse demand equation in Column (4) of Table 5. Output prices are plant-level prices relative to yearly PPI. Shares are estimated as the fraction of plant output in total output. 
Table 7: Persistence of TFP, Demand Shocks, and Output Prices

\begin{tabular}{lcccccccc}
\hline \hline \multirow{2}{*}{ Regressor } & \multicolumn{2}{c}{ TFP } & & \multicolumn{2}{c}{ Demand Shocks } & & \multicolumn{2}{c}{ Output Prices } \\
\cline { 2 - 3 } One-period Lag of & $(1)$ & $(2)$ & & $(3)$ & $(4)$ & & $(5)$ & $(6)$ \\
Dependent Variable & 0.9221 & 0.896 & & 0.9853 & 0.9871 & & 0.9925 & 0.982 \\
One-period Lag of Dependent & $(0.0018)$ & $(0.0029)$ & & $(0.0009)$ & $(0.0014)$ & & $(0.0013)$ & $(0.0026)$ \\
Variable $\times$ Post Reforms & & 0.043 & & & -0.0033 & & & 0.0144 \\
Year Effects & & $(0.0037)$ & & $(0.0019)$ & & & $(0.003)$ \\
$\mathrm{R}^{2}$ & YES & YES & & YES & YES & & YES & YES \\
$\mathrm{N}$ & 0.782 & 0.7824 & & 0.9305 & 0.9305 & & 0.868 & 0.868 \\
& 73,063 & 73,063 & & 85,576 & 85,576 & & 85,576 & 85,576 \\
\hline \hline
\end{tabular}

Notes: Standard errors are in parentheses. The table reports coefficients on lagged TFP, lagged demand shocks, and lagged output prices in the first and second, third and fourth, and fifth and sixth columns, respectively. All regressions include year effects. The TFP variable is estimated as the residual from the regression in Column (4) of Table 3 and the demand shock variable is estimated as the residual from the regression in Column (4) of Table 5. Output prices are plant-level prices relative to yearly PPI. 
Table 8: Cross-Section Decomposition of Three-Digit Level TFP and Demand Shocks, 1982-1998

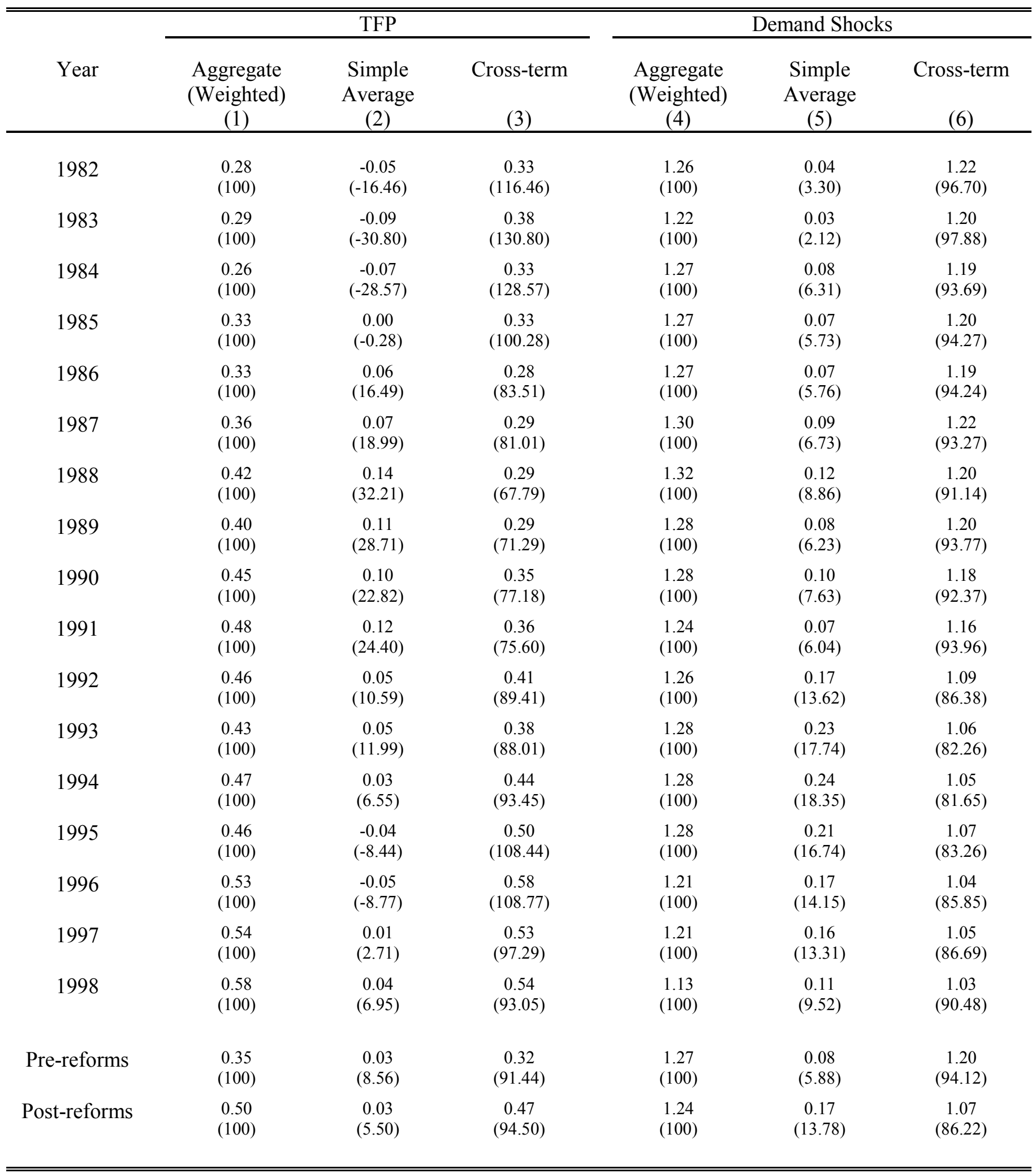

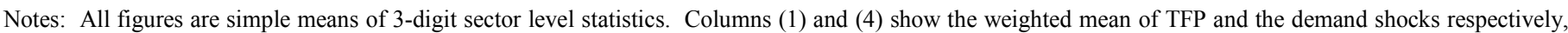

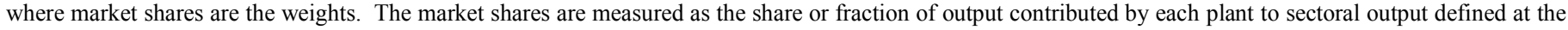

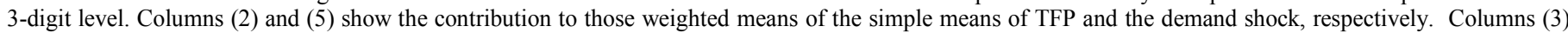

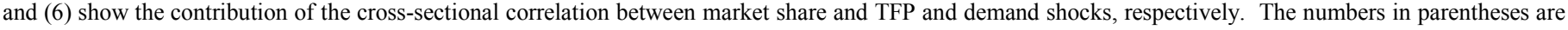
the fractions represented by each component. 
Table 9: Decomposition of Conditional Means of TFP and Demand Shocks, Before and After Reforms

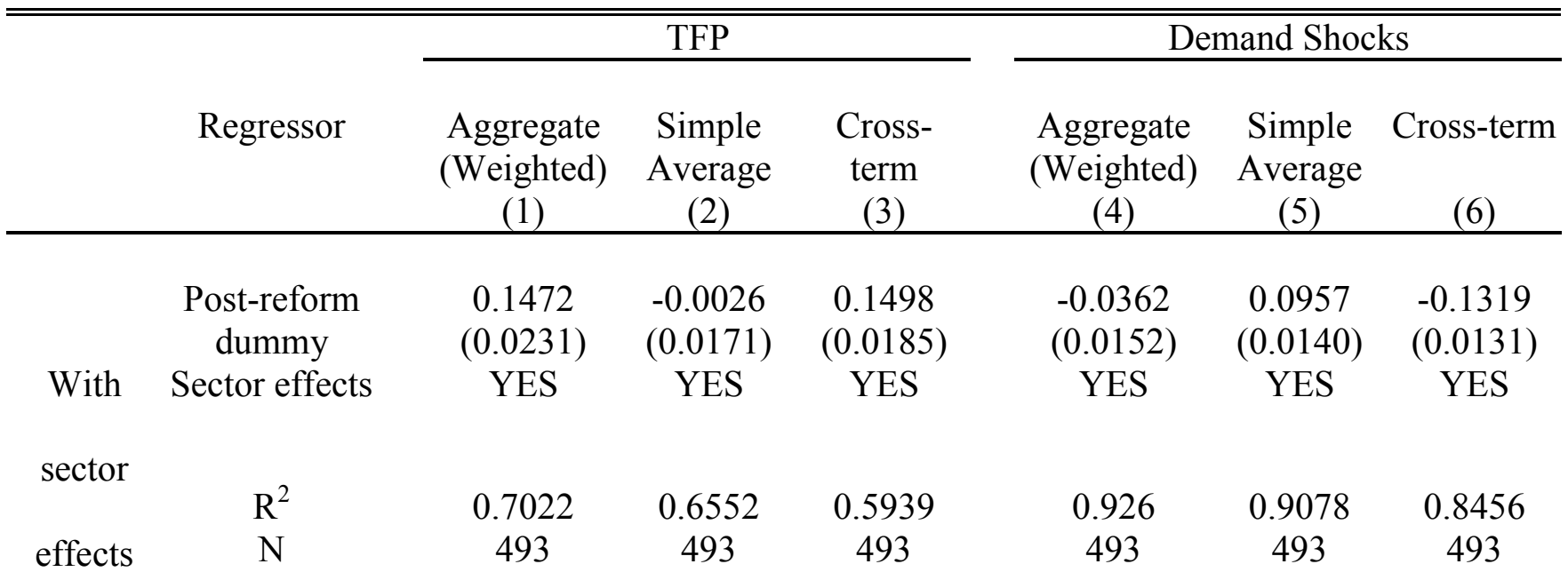

\footnotetext{
Notes: Standard errors are in parentheses. The table reports coefficients of a regression of one term of TFP or demand decomposition on a constant and a post-reform dummy. The regression is at 3-digit level. The post-reform dummy takes the value of 1 in 1991-1998, 0 otherwise. In columns (1) and (4) the dependent variable is the weighted mean of TFP and the demand shocks respectively, where market shares are the weights. In columns (2) and (5) the dependent variable is the simple mean of TFP and demand shocks, respectively. In columns (3) and (6) the dependent variable is the cross-sectional correlation between market share and TFP and demand shocks, respectively.
} 
Table 10: Evolution of TFP, Demand Shocks, and Output Prices

\begin{tabular}{|c|c|c|c|c|c|c|c|c|c|c|c|c|}
\hline \multirow[b]{2}{*}{ Regressor } & \multicolumn{4}{|c|}{ TFP } & \multicolumn{4}{|c|}{ Demand Shocks } & \multicolumn{4}{|c|}{ Output Prices } \\
\hline & $(1)$ & $(2)$ & (3) & $(4)$ & $(5)$ & $(6)$ & (7) & $(8)$ & $(9)$ & $(10)$ & $(11)$ & (12) \\
\hline Entry & $\begin{array}{c}0.0288 \\
(0.0115)\end{array}$ & $\begin{array}{c}0.0592 \\
(0.0148)\end{array}$ & $\begin{array}{l}0.0847 \\
(0.014)\end{array}$ & $\begin{array}{c}0.121 \\
(0.0178)\end{array}$ & $\begin{array}{l}-0.4354 \\
(0.0094)\end{array}$ & $\begin{array}{l}-0.4441 \\
(0.0123)\end{array}$ & $\begin{array}{l}-0.4681 \\
(0.0111)\end{array}$ & $\begin{array}{l}-0.4808 \\
(0.0143)\end{array}$ & $\begin{array}{l}0.0257 \\
(0.007)\end{array}$ & $\begin{array}{c}0.0119 \\
(0.0091)\end{array}$ & $\begin{array}{c}0.0386 \\
(0.0084)\end{array}$ & $\begin{array}{c}0.0319 \\
(0.0108)\end{array}$ \\
\hline $\begin{array}{l}\text { Entry } \times \\
\text { Post-ref. }\end{array}$ & & $\begin{array}{l}-0.0771 \\
(0.0235)\end{array}$ & & $\begin{array}{l}-0.0968 \\
(0.0288)\end{array}$ & & $\begin{array}{c}0.021 \\
(0.0191)\end{array}$ & & $\begin{array}{c}0.0341 \\
(0.0228)\end{array}$ & & $\begin{array}{c}0.0339 \\
(0.0141)\end{array}$ & & $\begin{array}{c}0.0192 \\
(0.0173)\end{array}$ \\
\hline 1-prd. Lag & & & $\begin{array}{c}0.0938 \\
(0.0133)\end{array}$ & $\begin{array}{c}0.0986 \\
(0.0157)\end{array}$ & & & $\begin{array}{l}-0.3941 \\
(0.0123)\end{array}$ & $\begin{array}{l}-0.4002 \\
(0.0147)\end{array}$ & & & $\begin{array}{c}0.0242 \\
(0.0093)\end{array}$ & $\begin{array}{c}0.0265 \\
(0.0111)\end{array}$ \\
\hline $\begin{array}{l}\text { of Entry } \times \\
\text { Post-ref. }\end{array}$ & & & & $\begin{array}{l}-0.0201 \\
(0.0296)\end{array}$ & & & & $\begin{array}{c}0.0212 \\
(0.0269)\end{array}$ & & & & $\begin{array}{l}-0.0058 \\
(0.0204)\end{array}$ \\
\hline $\begin{array}{l}\text { 2-prd. Lag } \\
\text { of Entry } \\
\text { 2-prd. Lag }\end{array}$ & & & $\begin{array}{l}0.0644 \\
(0.014)\end{array}$ & $\begin{array}{c}0.047 \\
(0.0165)\end{array}$ & & & $\begin{array}{l}-0.3484 \\
(0.013)\end{array}$ & $\begin{array}{l}-0.3696 \\
(0.0155)\end{array}$ & & & $\begin{array}{c}0.0138 \\
(0.0099)\end{array}$ & $\begin{array}{c}0.008 \\
(0.0118)\end{array}$ \\
\hline $\begin{array}{l}\text { of Entry } \times \\
\text { Post-ref. }\end{array}$ & & & & $\begin{array}{l}0.0617 \\
(0.031)\end{array}$ & & & & $\begin{array}{c}0.0731 \\
(0.0284)\end{array}$ & & & & $\begin{array}{c}0.0217 \\
(0.0216)\end{array}$ \\
\hline Exit & $\begin{array}{l}-0.2497 \\
(0.0102)\end{array}$ & $\begin{array}{l}-0.2262 \\
(0.0141)\end{array}$ & $\begin{array}{l}-0.2666 \\
(0.0122)\end{array}$ & $\begin{array}{l}-0.2408 \\
(0.0172)\end{array}$ & $\begin{array}{l}-0.4664 \\
(0.0094)\end{array}$ & $\begin{array}{l}-0.4589 \\
(0.0132)\end{array}$ & $\begin{array}{c}-0.4829 \\
(0.011)\end{array}$ & $\begin{array}{l}-0.4885 \\
(0.0156)\end{array}$ & $\begin{array}{c}0.0306 \\
(0.0069)\end{array}$ & $\begin{array}{c}0.0087 \\
(0.0098)\end{array}$ & $\begin{array}{c}0.0319 \\
(0.0083)\end{array}$ & $\begin{array}{c}0.0018 \\
(0.0118)\end{array}$ \\
\hline $\begin{array}{l}\text { Exit } \times \text { Post- } \\
\text { reforms }\end{array}$ & & $\begin{array}{l}-0.0485 \\
(0.0204)\end{array}$ & & $\begin{array}{l}-0.0519 \\
(0.0244)\end{array}$ & & $\begin{array}{l}-0.0152 \\
(0.0188)\end{array}$ & & $\begin{array}{l}0.0117 \\
(0.022)\end{array}$ & & $\begin{array}{c}0.0438 \\
(0.0139)\end{array}$ & & $\begin{array}{c}0.0608 \\
(0.0167)\end{array}$ \\
\hline $\begin{array}{l}\text { 1-prd. Lead } \\
\text { of Exit } \\
\text { 1-prd. Lead }\end{array}$ & & & $\begin{array}{l}-0.1826 \\
(0.0131)\end{array}$ & $\begin{array}{l}-0.1339 \\
(0.0173)\end{array}$ & & & $\begin{array}{l}-0.4028 \\
(0.012)\end{array}$ & $\begin{array}{l}-0.4675 \\
(0.0157)\end{array}$ & & & $\begin{array}{c}0.0184 \\
(0.0091)\end{array}$ & $\begin{array}{l}-0.0442 \\
(0.0119)\end{array}$ \\
\hline $\begin{array}{l}\text { of Exit } \times \\
\text { Post-ref. }\end{array}$ & & & & $\begin{array}{l}-0.1144 \\
(0.0266)\end{array}$ & & & & $\begin{array}{c}0.1534 \\
(0.0242)\end{array}$ & & & & $\begin{array}{c}0.1481 \\
(0.0183)\end{array}$ \\
\hline $\begin{array}{l}\text { 2-prd. Lead } \\
\text { of Exit }\end{array}$ & & & $\begin{array}{l}-0.1321 \\
(0.0136)\end{array}$ & $\begin{array}{c}-0.129 \\
(0.0179)\end{array}$ & & & $\begin{array}{l}-0.3371 \\
(0.0125)\end{array}$ & $\begin{array}{l}-0.3589 \\
(0.0165)\end{array}$ & & & $\begin{array}{c}0.022 \\
(0.0095)\end{array}$ & $\begin{array}{c}0.0131 \\
(0.0125)\end{array}$ \\
\hline $\begin{array}{l}\text { 2-prd. Lead } \\
\text { of Exit } \times \\
\text { Post-ref. }\end{array}$ & & & & $\begin{array}{l}-0.0077 \\
(0.0275)\end{array}$ & & & & $\begin{array}{c}0.0516 \\
(0.0252)\end{array}$ & & & & $\begin{array}{c}0.021 \\
(0.0191)\end{array}$ \\
\hline $\begin{array}{l}\text { Year } \\
\text { Effects }\end{array}$ & YES & YES & YES & YES & YES & YES & YES & YES & YES & YES & YES & YES \\
\hline $\mathrm{R}^{2}$ & 0.0151 & 0.0153 & 0.0162 & 0.0169 & 0.0610 & 0.0610 & 0.1078 & 0.1086 & 0.0036 & 0.0038 & 0.0026 & 0.0038 \\
\hline $\mathrm{N}$ & 76,261 & 76,261 & 56,025 & 56,025 & 88,690 & 88,690 & 65,398 & 65,398 & 88,690 & 88,690 & 65,398 & 65,398 \\
\hline
\end{tabular}

Notes: Standard errors are in parentheses. The TFP variable is estimated as the residual from the regression in Column (4) of Table 3 and the demand shock variable is estimated as the residual from the regression in Column (4) of Table 5. Entry is a dummy which takes the value of one if the plant entered that period and zero otherwise, and the one- and two-period lags are dummies that take the value of one if the plant entered last period or two periods ago and zero otherwise. A plant entered in period $t$ if it reported positive production in period $t$ but not in period $t-1$. Exit is a dummy which takes the value of one if the plant exits this period and zero otherwise, and the one- and two-period leads are dummies that take the value of one if the plant exits one or two periods ahead. A plant exited in period $t$ if it reported positive production in period $t$ but not in period $t+1$. 